\title{
THE GOSPEL ACCORDING TO GRACE: \\ GNOSTIC HERESY AS NARRATIVE STRATEGY IN MARGARET ATWOOD'S ALIAS GRACE
}

\author{
by \\ Ryan Edward Miller \\ B.A., University of British Columbia/ \\ University College of the Cariboo, 1997 \\ THESIS SUBMITTED IN PARTIAL FULFLLMENT OF \\ THE REQUIREMENTS FOR THE DEGREE OF \\ MASTER OF ARTS \\ in the Department \\ of \\ English \\ (c) Ryan Edward Miller 2000 \\ SIMON FRASER UNIVERSITY \\ October 2000
}

\begin{abstract}
All rights reserved. This work may not be reproduced in whole or in part, by photocopy or other means, without permission of the author.
\end{abstract}


National Library

of Canada

Acquisitions and Bibliographic Services

305 Wcinington Sirent OWme ON K1A ON Cenade
Bibliotheque nationale

du Canada

Acquisitions et services bibliographiques

395, nu Wolington

Otima ON K1A ONA

Canda
Your to vason numese

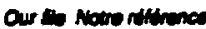

The author has granted a nonexclusive licence allowing the National Library of Canada to reproduce, loan, distribute or sell copies of this thesis in microform, paper or electronic formats.
L'auteur a accordé une licence non exclusive permettant à la Bibliothèque nationale du Canada de reproduire, prêter, distribuer ou vendre des copies de cette thèse sous la forme de microfiche/film, de reproduction sur papier ou sur format électronique.

L'auteur conserve la propriété du droit d'auteur qui protège cette thèse. $\mathrm{Ni}$ la thèse ni des extraits substantiels de celle-ci ne doivent être imprimés ou autrement reproduits sans son autorisation.

\section{Canadä}




\section{ABSTRACT}

This thesis approaches Margaret Atwood's 1996 novel Alias Grace with specific attention to the author's use of Gnosticism in the creation of a unique and complex feminist narrative. This is an original topic: one not previously cited in Atwood criticism. A product of history and invention, Alias Grace embodies a speculative approach to female criminality as it was received in the colonies during the early to mid-nineteenth century. Offering her novel as a parodic response to the wild-eyed murderesses of Victorian fiction, Atwood explores Grace's crime and confinement through a lens of Biblical/historical construction, imagining how an incarcerated woman might respond to those processes, while communicating also the privatization of "self" as conceptualized by Gnostic symbol and myth.

Key to the author's strategy are Alias Grace's supporting characters, Mary Whitney and Jeremiah the peddler. Their initiation of Grace into Gnosticism offers the latter a unique freedom, but foregrounds what - in terms of nineteenth-century Christianity - was widely considered heresy. Taught that the only good Father is an absent one, and that laws were meant to be broken, Grace locates in the "strange teachings" of Gnosticism a way of refuting then-contemporary judgments of her actions. As a murderess, Atwood's Grace is unlike her fictional counterparts: she is quietly intelligent and keenly aware of narrative politics. Her Gnostic re-telling of history - recounted for psychologist Simon Jordan - becomes the novel's primary means of subversion: a narrative sleight-of-hand by which the principal 
ideology of Gnosticism might be passed onto others - but only, we find, to those like Simon who might recognize and accept new doctrines.

Atwood's use of Gnostic myth brilliantly locates the potential for feminist licence in a historical crisis of faith. My reading proposes that she is using this understanding of gnosis - or self-knowledge - as a playful attempt to localize in Grace Marks the alienation and suffering of the divine feminine. Recalling specific doctrines such as the Simonian myth of Simon and Helen, or the redemption of the Sophia figure, Alias Grace is a profound addition to Atwood's earlier feminist narratives, while offering a pointed comment on the value of history and historical fiction. 
This project is dedicated to my wonderful family, for all their love and support.

And to Bob and Deli, for injecting a lighter note. 


\section{ACKNOWLEDGMENTS}

My gratitude to Professor Sandra Djwa for her guidance and support during the course of this project, and for suggesting "The Gospel" as a title. My thanks also to Professors David Stouck and Margery Fee, who graciously came aboard to lend assistance; and to Margaret Atwood, for her kind permission to include certain materials. Without them, there could be no "Grace" under pressure.

To Tracy Wyman-Marchand - proof positive there are warriors among us - you are, in your kindness and laughter, other-timely.

To Anita Mahoney - whose invaluable technical assistance allowed for the creation of a unique research tool - I thank you.

And thank you, Phyllis. Per tutto quello che mi hai insegnato. 


\section{TABLE OF CONTENTS}

Approval ii

Abstract iii

Dedication v v

Acknowledgments vi

I Becoming: An Introduction 1

II These Teachings Are Strange Ideas: $\quad 27$

Reading Mary Whitney

III "Jeremiah, Blow the Fire": 47

Raising the Divine Spark in Alias Grace

IV Failing the Gnosis Test:

58

Simon Jordan and the Gnostic Potential

$\begin{array}{lll}\text { V The Gospel According to Grace } & 77\end{array}$

VI Conclusion (Thrice-Crossed Waters) 94

$\begin{array}{ll}\text { Notes } & 101\end{array}$

$\begin{array}{ll}\text { Works Cited } & 103\end{array}$

$\begin{array}{ll}\text { Works Consulted } & 108\end{array}$ 
I

Becoming: An Introduction 
"If you're after the truth, the whole and detailed truth, and nothing but the truth, you're going to have a thin time of it if you trust to paper; but with the past, it's almost all you've got" (Atwood, "In Search of Alias Grace" 1514). Thus began the construction of Alias Grace (1996), Margaret Atwood's ninth and, arguably, her most ambitious novel todate. Based on the 1843 murders of a gentleman and his housekeeper in rural Ontario, Atwood's foray into criminal representations of the nineteenth century began as an exercise in social and cultural anthropology - "the digging up of buried things," she says (1509) which for Grace Marks meant resurrecting some of Canada's long-forgotten history. "What's on [all that] paper?," she inquires. "The same things that are on paper now. Records, documents, newspaper stories, eyewitness reports, gossip and rumor and opinion and contradiction [...] [ultimately] no more reason to trust something written down on paper then than there is now" (1513). To negotiate a space for herself, then, and "to be fair [...] to represent all points of view," she devised a series of guidelines by which she would view her writing; in part, stating that "when there was a solid fact, I could not alter it [. . . [b]ut in the part left unexplained - the gaps left unfilled - I was free to invent" (adding later that "since there were a lot of gaps, there is [also] a lot of invention") (1515). In and of itself, such an approach is not an uncommon practice in historical narratives. Instead, it is Atwood's admission of a fiction equal to, or greater than, the novel's use of history that redirects our attention here, inviting an examination not so much of how Alias Grace elicits Canada's past, but rather, what is occurring adjacent to it.

Atwood has certainly led us to this boundary before. In The Journals of Susanna Moodie (1970), for example, she documents the immigrant experience of the real Susanna 
Moodie as first introduced in Roughing $t$ in the Bush (1852), but heightens Moodie's cautionary tale with a new sensibility or aesthetic; in that case, using the typically historical act of journal writing as a vehicle from which to project the uncertainties and fears of Northrop Frye's "garrison mentality." The Handmaid's Tale (1986) is a good example of this also, using its "historical notes" as parody: disseminating "historical" knowledge of the fictive Gilead in convincingly real terms. For her retum to the nineteenth century in Alias Grace, Atwood shows herself to be less tongue-in-cheek, but still willing to play into those earlier anxieties. Bringing together discussions of criminality, religious heresy, and mental illness, she imagines through Grace's eyes an unforgiving world of crime and punishment; of propriety and hypocrisy; and - most importantly here - of holism and disembodiment. What separates the novel most visibly from earlier endeavors, however, is that its use of fiction does not embroider or complement what is historically well-documented, as it does in The Journals. Instead, it seeks to bridge those questions for which the past has exhibited an absence of definitive knowledge - drawing explanations of the fantastic to account for what are otherwise unknowable truths.

Central to this is the character of Grace Marks. Public opinion may have divided her, but out of that process one thing became clear: "people began writing about her," Atwood tells us, "projecting onto her all of the received opinions of women, about criminality, about servants, about insanity, sexuality [...]. So I was interested in that [...] in the process of public opinion and how it's formed [.. . ] how each person, even people who are witnesses, have their own version (Atwood, "Natural Bom Quilter"). Given her awareness, then, that those around Grace were themselves fictionalizing, it comes as little surprise that her novel 
should offer its own model. Recalling Linda Hutcheon's views of The Canadian Postmodern and "historiographic metafiction," Atwood's strategy here is a familiar emphasis of process over product. Exploring less the question of Grace's innocence or guilt and more the social machinations that have rendered her a murderess, the novel complicates its own ontology by asking - as Hutcheon does - "what exactly can be said to constitute fact and fiction - life and art?" (68).

Atwood's use of artistic strategies informs the difficulties she and others have found when attempting to offer an accurate reflection of the past. Writing Grace's narrative has become, then, a process reliant upon the author's use of historiography, biography, and "novels set in the historic past" to achieve some sense of postmodern immediacy. We could attribute this - as she does - to the contradictions and omissions inherent to Grace's story; for "the writers-down," Atwood explains, "[. . .] were human beings, [and like anyone they are] subject to error, intentional or not, and to the very human desire to magnify a scandal, and to their own biases" ("In Search of Alias Grace" 1514). Or, we might find within those limitations the "gaps" she mentions earlier; that is, a novelist's opportunity for invention, for response. At issue here are questions of - as l've said - life and art, but also of representation and, more visibly, of textual and historical authority. For her part, the Grace we find in the novel is also cognisant of these issues: "I think of all the things that have been written down about me," she confides, "[. . . ] and I wonder, how can I be all of these different things at once?" (Alias Grace 23). And so, while trying to provide an answer to the question "Who is Grace Marks?" Atwood reminds us of the individual's role in the production of that text. ${ }^{2}$ By inverting that structure - by offering a space in which Grace 
herself might respond - she unfolds in Alias Grace a novel which, in the guise of trying to prevent us from knowing something, actually tells us something else. And perhaps we should not be surprised. For "whatever else she is," the author reassures, "[my Grace] is a storyteller with strong motives to narrate but also strong motives to withhold; [and ultimately,] the only power left to her as a convicted and imprisoned criminal comes from a blend of these two motives" ("In Search of Alias Grace" 1515).

It is within this nexus, I shall argue later, that the true interest of the novel lies.

For now I turn to recent attention given to Alias Grace in American Historical Review; and in particular, to an article written by Jonathan D. Spence in response to Margaret Atwood's essay "In Search of Alias Grace." Challenging her methodologies for their omission of a defined perimeter between author and historian, Spence broaches what I believe to be an important consideration when first approaching the novel; namely, the question of who reserves the authority to write about the past and, moreover, what stories should be told. "[...] [П]n and of itself," Atwood might remind us, the past "tells us nothing. We have to be listening, first, before it will say a word, and, even so, listening means telling, and then re-telling" (1515-6). Such things may be true; in practice, however, their application is less concrete. Spence, for instance, is guarded towards such generalizations. "Like Atwood," he explains, "I am drawn into the act of writing by my absorption with "[. ..] individual characters interacting with, and being acted upon by, the world that surrounds them'." And yet, "[...] where, then, are the crucial differences in what we do?" he asks (1523). "Partly," he decides, 
[.. .] they lie in the zones of freedom that we allow ourselves. Atwood is precise about the three guidelines she followed in composing Alias Grace: first, "[...] when there was a solid fact," she could not alter it; second, "every major element in the book had to be suggested by something in the writing about Grace and her times, however dubious such writing might be"; third, "in the parts left unexplained - the gaps left unfilled - [she] was free to invent." It is with this list of guidelines that a historian like myself, deeply drawn to her other arguments, starts to separate himself out from the overlays between a novelist's sensibilities and a novelist's procedures.

And yet one wonders if this separation is truly possible, or important. Hayden White informs us that narrativizing history - regardless of profession - is rooted in a larger desire to participate in "that finding of the 'true story,' that discovery of the 'real story' within or behind the events that come to us in the chaotic form of "historical records"' (White 276). Hutcheon's Canadian Postmodern, also, is useful in bringing to light the "shared, 'emplotting,' strategies of exclusion, emphasis, and subordination" practiced by both novelists and historians (66). Unless the latter choose to utilize a mode of historical representation that is non-narrative in form (White suggests here "the annals, the chronicles, or the history proper"), he or she is destined to engage in the same practice in which Atwood is engaged: storytelling. And so, when Spence asserts that "the historian knows that much time is spent trying to determine whether or not something is 'solid fact,"' just as the historian "is [also] not 'free to invent' whenever he or she finds gaps left unfilled," informed readers will recognize that he negates his own involvement in that process. ${ }^{+}$

Such issues are likely not lost on Atwood, even if the novel itself reveals a lesser concern about making those distinctions. For all its transgressions, her means of assembling the past does not forsake what Hutcheon might call the novel's "essentially literary nature" (68), nor does it treat historical approaches more vigilant than her own lightly. Instead, one 
begins to wonder if this is truly the point: that a narrative, regardless of origin or whatever authority we may place upon it, is still a narrative: a construction - influenced as much by its author as it is by the social influences through which he or she is working. Given her familiarity with the genre, it is reasonable to assume that Atwood is aware of this; and indeed, others such as Lynn Hunt question "whether this [distinction of profession] is really the vital issue for those who write history [...]. She [Atwood] takes more or less for granted the difference between history and fiction [...] and so, I will argue, should historians" (Hunt 1517). For the purposes of this thesis, then, I am concerned less with the implications of Atwood's methodologies, and more with what is occurring with the novel's complication of boundaries: on one hand, the blurring of the fictive and historical with respect to Grace Marks's "history"; and secondly, the valorization - and conversely, the Victorians' rejection - of "private" versus public literatures. While history is inextricably united to those discussions, Alias Grace serves a greater analysis of how the historic past can afford opportunities of a subversive nature; and similarly, how a work seemingly emphasizing the authenticity of the "private" can, like Hutcheon's "historiographic metafiction," prove itself "intensely, self-reflexively art, but [. . .] grounded [also] in historical, social, and political realities" (Hutcheon 13).

It is useful, then, when first approaching the subject of historical fiction to consider Judith Knelman's reminder that embedding fictional elements within a historical context results in what is merely "the effect of history" (Knelman, "Can We Believe..." 685) - that is, it feels historical to the reader when much of it is actually the product of careful invention (or, as Gabrielle Spiegel points out, "an index of socially construable meaning rather than 
an image of reality"). When we look to Alias Grace, we see the historical novel, but we see also Atwood's parodic use of the genre. Like Famous Last Words by Timothy Findley, or Rudy Wiebe's The Temptations of Big Bear, she complicates the line between fact and fiction - essentially, questioning historical "fact" - by utilizing both real and invented characters, and allowing the words of those invented persons to bear equal weight to the novel's historical counterparts. The result is a historical novel which appears, by its seeming defiance of that authority, ahistorical. And perhaps this too is the point. "But," Atwood interrupts to ask, "what exactly do we mean by 'historical novel'?"

All novels are in a sense 'historical' novels; they can't help it, insofar as they have to, they must, make reference to a time that is not the time in which the reader is reading the book. But there is the past tense - yesterday and yesterday and yesterday, full of tooth flossing and putting antifreeze into the car, a yesterday not so long ago - and then there is The Past, capital T and P [.. . ]. [N]ot all [authors] use the past for the same purposes. Of course not; the authors of [history] are individuals, and each novel has its own preoccupations. Some attempt to give more-or-less faithful accounts of actual events, in answer perhaps to such questions as "Where did we come from and how did we get here?" Some attempt restitution of a sort, or at least an acknowledgment of past wrongs [...]. Yet others unearth a past as it was lived by women, under conditions a good deal more stringent than our own. ("In Search of Alias Grace" 1510).

And this, it seems, is exactly what Alias Grace attempts to do: to elicit a history that has been forgotten, or lost; or perhaps even buried (buried things being more preferable to write about, of course, than merely forgotten ones). Granted, the approach Atwood takes toward her subject here connotes a certain playfulness, but ultimately she is serving the novel's more serious undertones: specifically, the processes by which histories are assembled or written; how each of those texts speaks to the other; and which stories among them are most likely to be lost in the process. 
Exploring the life of the real Grace Marks from the time of her emigration to Canada in the 1830s until her release in 1872 from the Kingston Penitentiary, we are reminded by the author's dealings with "gossip and rumor and opinion and contradiction" that achieving a sense of wholeness in historical narratives is a nebulous process. "The fullness of Grace is the point," Atwood tells us ("Natural Born Quilter"); but as a reader, what is Alias Grace's position here? Is it history, for history? Or is hers a novel like any other, only set amongst the Victorians? Admittedly, the author's backward gaze is initially misleading: her entrance to the subject suggests a curiosity typically expected from a novelist such as herself, and yet the novel's approach to Grace's life - while anthropological in nature - furthers a line of parodic interplay between the author's presentation of life and art, history and fiction. The suggestion is, of course, that the endeavors pursued by novelists and historians are successful because, ultimately, they owe their constructions to the same family of processes. However, we see something else too: in Atwood's world, history can become fiction. And fiction, she might argue, can be the art of history.

One thing of which most would agree when approaching Alias Grace is that Grace Marks herself is not the obvious subject of historical fiction, primarily because - as I've said - there is little available history from which to draw. What is there, however, tells us that Grace Marks was a murderess; that she was celebrated for her infamy and, depending on whose account you believe, got what she deserved. In many ways she is Atwood's Lizzie Borden. Her appeal stems not so much from the reflection she offers of social climate, but from the idea that she upset Victorian ideals of the feminine to participate in a grotesque crime. Who exactly Grace Marks was - particularly as a servant girl among the Victorian 
upper class - has never been much of a consideration. Initially, such distinctions might seem unimportant; yet, "[. . . ] whoever tells you that history is not about individuals, only about large trends and movements,"Atwood reminds us, "is lying" ("In Search of Alias Grace" 1505). To explore those omissions, then, is to give voice to the voiceless: to explore why memory allows for the preservation of some things while excluding others. Historically, Grace's account of the murders - however truthful or untruthful it might have been - proved of lesser consequence than the perceptions that were drawn of her..$^{5}$ And this is a crucial awareness in the novel: not that she was "innocent" or "guilty," but that the history she embodied was discounted in favor of more sensationalized (orthodox) representations. To present that process as an opposition of canonicities in Alias Grace is, therefore, to remind us of the stories that are not included. And perhaps rightly so. Tales such as Grace's, the author would argue, are ultimately not about "this or that slice of the past [...] [but are] about human nature [. . . ] about truth and lies, disguises and revelations [. . . ]. [They are] about long suffering and charity [.. .] sin and retribution, and sometimes even redemption" (1516).

With an eye to some of these issues, then, Margaret Atwood's interest in Grace Marks seems two-fold: on one hand, the attraction of the Kinnear-Montgomery murders (and Grace's subsequent infamy) is formidable. Encompassing the familiars of gender, class, and identity - each of which stood in stark opposition to the Victorian ideal - the infamy of Grace Marks is, and has been, fertile ground for Atwood. Having written of Grace previously in the 1974 teleplay "Grace Marks" (broadcast as The Servant Girl for the Canadian Broadcasting Corporation), and again in 1979 in an unproduced stage play entitled, 
simply, "Grace," Alias Grace marks the author's third pass at her subject, yet is also perhaps her best opportunity to address the social realities therein. ${ }^{6}$ Allied with this, however, is a secondary interest: arguably, an opportunity for the author to correct herself: to re-position her portrayal of Grace given a matured understanding of the circumstances by which her subject was defined. ${ }^{7}$ Recalling her initial dependence on Moodie's Life in the Clearings (1853) for information about the case - a narrative in which Moodie's Grace appears as a raving madwoman - Atwood remarks: "[t]hat was the first version of the story I came across and, being young, and still believing that 'non-fiction' meant 'true,' I did not question it" (1513). Not surprisingly, those early portrayals closely follow Moodie's version, and from all appearances, Atwood herself seemed to embrace them. Yet, "[. . . ] [i]t always bothered me that the story Moodie told was so theatrical," she confides. "It made you wonder: could it really have been like that?" (Atwood, Interview). When contemplating the direction Alias Grace should take, then - when exploring what else might have been occurring to influence the outcome - Margaret Atwood did what, until then, she had not done: she returned to the past.

What she found there surprised even her. Susanna Moodie had been writing the case from memory, and "[. . . ] as it turns out," Atwood says, "[Moodie's] memory was no better than most. She got the location wrong, and the names of some of the participants, just for starters. Not only that, the actual story was much more problematic, though less neatly dramatic, than the one Moodie told" ("In Search of Alias Grace" 1514). In the Afterword to the novel also, and again at the Stratford Festival in September 1997, Atwood goes further to explain why that early account is now suspect: 
Moodie's retelling of the murder is a third-hand account. In it, she identifies Grace as the prime mover, driven by love for Thomas Kinnear and jealousy of Nancy, and using the promise of sexual favors to egg McDermott on [. . . . Moodie can't resist the potential for literary melodrama, and the cutting of Nancy's body into four quarters is not only pure invention, but pure Harrison Ainsworth. (Afterword, Alias Grace 464)

[In real life] James McDermott declared that Grace had helped him strangle Nancy, and [that she] was the instigator of the whole affair. Although he was a known liar, his is the version Moodie chose to believe. Why? Partly because it makes Grace a stronger and more fascinating character. If she was just a terrorized victim - as she herself claimed - there's a lot less of her for dramatic purposes, which include blood, guilt, haunting, and madness as God's vengeance, Greek tragedy, Macbeth, and much Victorian melodrama [. . .]. [And, regarding Nancy's eyes, of whom Grace was supposedly haunted:] This is Lady MacBethland, complete with visual hallucinations. It's also Charles Dickens, who was much influenced by the theater of his day. The glaring, haunting eyes ominously close to those of the murdered Nancy in Oliver Twist [. . .]. It's noteworthy that Dickens was one of Susanna Moodie's favorite authors, and that Moodie is the only commentator who calls Nancy "Hannah." Could it be that she herself was aware of the resemblance between the two Nancys, and changed that name to deflect attention away from it?' (Atwood, "Ophelia Has a Lot to Answer For")

Using Alias Grace as a point from which to distance herself, then - both from Moodie's account of Grace and from her own early characterizations - Margaret Atwood shifts the emphasis of the novel toward the aspects of Grace's character that we don't know: that is, how awful the truth might be. In doing so, she embraces an ambiguity that many of Grace's real-life commentators tried to avoid, recognizing that if murderess is a label attributable to "the received opinions of women," it is also the reception of what Karlene Faith terms the "unruly woman."10 And it is here, in this awareness of nineteenth-century criminal reception, that the novel's approach to Grace Marks finds its roots.

I use Karlene Faith's Unruly Women as a place to begin here, as it is one of few recent works to displace notions of "deviancy" and contextualize female criminality as the 
transgression of social order. Chronicling in part the nineteenth-century's connections between female misconduct and the moral distinctions applied to prostitutes, adulterers, and all others who threatened the family unit, Faith's tome effectively restates the sexual and moral ambiguity felt toward women during this period. ${ }^{11}$ Indeed, it is the violated ideal, and not a specific illegality, which grounds us here. "When apprehended for crossing the boundaries of legality," she writes, "[the 'unruly woman'] is punished as much for her betrayal of Womanhood as for her witting or unwitting failure to submit to The Law" (2). Atwood traces this also, noting that "[ . . ] usually [. . .] when there's a violent crime involving both a man and a woman [. . .] opinion is undivided about the man - he dunnit and divided about the woman" (Atwood, "Natural Born Quilter"). Because the "unruly woman" is judged dually, both for her actions as a criminal and for her betrayal of the culture in which she lived, it is not surprising when the crime of the female offender assumes a lesser, even peripheral, role in the procession toward justice.

Alias Grace reflects this also: the emphasis shifts away from the murders of Thomas Kinnear and Nancy Montgomery and toward the challenge of ascertaining Grace's character. Atwood does not make this easy: the Grace she imagines is reluctant to reveal too much of herself: "you should be careful about saying what you want or even wanting anything," she says, "as you may be punished for it" (Alias Grace 98). Atwood concentrates on what is happening around Grace; and indeed, like the Old Maid's Puzzle quilt, it is through this assembly of pieces that we learn what it is that she seems to desire. Preceding this recognition, however, the author's attempt to juxtapose Grace - an "unruly 
woman" herself - with the novel's more prominent archetypes of Victorian femininity reminds us that

two things told very much against Grace [. . . [ [first,] she was found at an inn with a man - and if you've read "The Mill on the Floss," you know that is almost automatically a fallen woman [...]. ${ }^{12}$ Number two, she wore Nancy's dress to the trial [ . . . [a decision which] told very much against her and produced a sensation in the courtroom. ("Blood and Laundry")

One could concede that the above reaction is in part attributable to the disparities that existed between social classes: the idea of Grace Marks, the servant, rising up to kill her employer would have been abhorred by those of middle-class standing or higher, presumably out of fear that the same might happen to them. And yet, the above passage speaks volumes as to the role of women as well. Atwood is, of course, well-practiced in the art of representation here (The Handmaid's Tale's "Unwoman" comes to mind, as does the consumption of Marian-cake in The Edible Woman). As with many of her novels, protagonists such as Grace serve as key figures in a continuing feminist mythology.

For Alias Grace, Margaret Atwood extends this further, playing into more gothic sensibilities: truths that can no longer be comfortably deduced using reason. What seems to concern her most, however, is the upset of moral order in the Victorian world: complicating popular conceptions of "right" and "wrong," or "good" and "evil." Such a move is befitting of her subject; for "[m]urder by a woman was so unthinkable in the patriarchal ideology of Victorian England," Judith Knelman writes, "that it had to be explained away as the action of a whore, witch, monster, or madwoman" (Twisting in the Wind 230). Naturally, Atwood takes advantage of this; in part, because it makes Grace a more interesting character, but also because it conveys an intelligence denied to her in the historical records. There comes a 
moment early in the novel when Grace is contemplating the public's interest in her that she muses: "they don't care if I killed anyone, I could have cut dozens of throats [. . . ]. No: was I really a paramour, is their chief concem, and they don't even know themselves whether they want the answer to be no or yes" (Alias Grace 27). While Atwood gives us some indication here as to social curiosities or the reception of female criminality, to look further into what was occurring during this period is to recognize that the public's infatuation with the murderess ran far deeper.

Grace's knowledge of the term is that "[. . . ] it is a strong word to have attached to you. It has a smell to it [. . .] musky and oppressive" (23). Not surprisingly, the murderess of Alias Grace assumes the figure of an apocalyptic bride: a shadow who is both passionate and ruthless; and to whom men like Simon Jordan find themselves inexplicably drawn (even when women of "purer" standing - such as the virginal Faith Cartwright - are readily available). Initially, Simon's desires may seem out of place here, yet Atwood is merely giving a nod to what was occurting in the literature of the time. While the early nineteenth century brought with it the advent of the true crime novel, it was Charles Dickens and Wilkie Collins, among others, who were instrumental toward positioning the murderess in contemporary nineteenth-century fiction. Their sensation novels - often inspired by actual cases - were such that " $[\ldots]$ murder by women became an expression of sexuality, broke the stereotype of the 'angel in the house,' [and] present[ed] the murderess as attractive, exotic, and passionate" (Knelman, Twisting in the Wind 30-1). Atwood's knowledge of these authors and their works certainly bears some influence here. Working through the Ange/Whore dichotomy, her positioning of Coventry Patmore's The Angel in the House 
alongside the real Grace's confession in her introduction to "The Letter X" suggests a concerted effort toward collapsing those earlier stereotypes (Alias Grace 328). Indeed, this is her true crime novel; and working within that genre, she seems intent on reiterating the central question surrounding the case: namely, "[ . . . was Grace a female fiend and temptress, the instigator of the crime [. . . or was she an unwilling victim, forced to keep silent by [James] McDermott's threats and by fear for her own life" (463). Certainly, Atwood knows that the ambiguity of McDermott's and Grace's relationship, and the seeming un-answerability of the question itself, accounts for much of the tale's allure. Moreover, given the wake of the Paul Bernardo and Karla Homolka trials in Ontario during the early 1990s - the period during which Alias Grace was conceived - it is likely that such a relationship would have been on her mind. ${ }^{13}$ We return, then, to the question of aliases: who is the real Grace Marks? The novel recognizes that answering this is difficult. "[S]he is a different person," Atwood allows, "[. . .] more ambiguous than the original character that I wrote, of course" ("Blood and Laundry"). And so, given my earlier promise - that within the nexus of Grace's storyteiling lies the true interest for the novel - it is here that I begin that discussion.

My thesis examines Margaret Atwood's use of Gnosticism in Alias Grace, with an eye to the agency it grants both author and character in the creation of a unique and complex feminist narrative. Initially, the novel does not suggest this at all: the Kinnear-Montgomery murders and the life of Grace Marks do not, historically, have any connection to Gnosticism, nor is its presence in the novel made overt. Nonetheless, the reader is conscious throughout the novel of recurring threads of religious symbolism which, while seemingly orthodox in 
some instances - such as the frequent references to the "Trinity" - lend themselves to very unorthodox conclusions in others. Leading the reader here are two things: first, the novel's use of water and dreams to imply some form of Gnostic chaos or hell (Alias Grace 139-40, 194-5); and secondly, the implicit ties Atwood draws between the spirit and self-knowledge: Grace's awareness of "[ . . .] being tom open; not like a body of flesh, [...] but like a peach, [. . .] too ripe and splitting open of its own accord" (69). Ultimately, to understand the carefully structured relationships between the novel's invented characters - and the significance of Grace's final "Tree of Paradise" design - an understanding of Gnosticism is essential. Atwood has, of course, played with other myths before: Surfacing and Lady Oracle are good examples. ${ }^{\text {t }}$ Simply put, this is what she does. And so, using close reading and historical/textual investigation as my primary method, I wish to explore this idea further as it relates to Gnosticism; and in doing so, draw upon various gender, psychological, or narratological discussions which - although done so loosely - might be taken as a theoretical approach here.

To begin my analysis, then, it is important for me to emphasize that Gnostic studies are by no means static. Indeed, Stefan Rossbach tells us in Gnostic Wars that even the definition of the term itself remains in contention. ${ }^{\text {I5 }}$ For the purposes of this thesis, however, I must make some allowances for clarity. And so, if I am to choose a working - albeit tentative - explanation of Gnosticism to aid my discussion, it would be this:

Gnosis [self-knowledge] promotes the soul, in its self-understanding, to an absolute position high above the un-reality of cosmic ignorance and suffering. From this outpost, the world must indeed appear as a totality, a "system." Through gnosis the actual experience of alienation is transformed into the "distance" required to be able to observe the cosmos from outside. The moral significance of this transformation, 
however, lies in the absoluteness of the boundaries which it creates between human beings. For if gnosis elevates the soul above the cosmos [.. . ] the unbridgeable gap which the classical thinkers perceived between the human and divine realms mutates into a gap between those with gnosis and those without. (Rossbach 230)

A second discussion of Gnosticism is also useful here in that it facilitates the introduction of this subject. I am referring here to Etsuko Taketani who, in his discussion of Gnosticism, tells us that:

Gnosticism postulates two origins, two Fathers, for the genealogy of the human race. Gnosticism argues that, although the inferior body was created by Jehovah (the Demiurge), man's innermost Self is related to the Unknown God (Forefather) who exists beyond the visible world created by the inferior God. The spiritual core of man has a kinship with the highest, eternal and unbegotten God beyond. It is a divine seed deriving from the Forefather. (Taketani)

In addition to the primacy granted by the Gnostic endeavor, a Gnostic re-telling of history in Alias Grace allows for Atwood's complication of boundaries; among them, the distinction between "public" and "private"; "fact" and "fiction"; and more visibly here, between "gospel" and "heresy." Of the more useful examples with which I might begin is the novel's positioning of the tale "Susannah and the Elders," at the point in which Grace enters the household of Thomas Kinnear and Nancy Montgomery at Richmond Hill. In "Susannah," the stress is on sexual sin. The older men desired Susannah and gave false testimony against her. However, because of the inconsistencies in those accounts, she is exonerated. Not only are there parallels between the two tales - in the sense that Grace may (or may not) be an innocent when she marries - but its presence also highlights in Biblical construction an extended metaphor for the dual processes of inclusion/exclusion that define Grace as well.

When informed by Thomas Kinnear that "Susannah" belongs to the Apocrypha stories decided, by men, not to be included in the Bible - Grace remarks: "Who decided? [. 
.. I was most astonished to hear this. I'd always thought that the Bible was written by God, as it was called the Word of God, and everyone termed it so" (Alias Grace 222). Yet, when one considers the tale itself - how a young woman is falsely accused by her male peers of having sinned - we receive our first indication of the connections Atwood intends between Grace's ideology and the construction of Christian dogma. Grace's decision that "the Bible may have been thought out by God, but it was written down by men. And like everything men write down, such as the newspapers, they got the main story right but some of the details wrong" reveals, among other things, a maturing awareness of the patriarchy's role with respect to narrative construction. Her choice to communicate those experiences through Gnostic symbol and myth - specifically, those from Orphic and Valentinian schools - finds her at once owing to the same language of signifiers, but doing so in manner that foregrounds and, ultimately, embraces the role of women observed outside Biblical/historical canons. ${ }^{16}$ At first glance, Atwood's choice of structure here could be seen as a continuation of Northrop Frye's "U-shaped narrative," and to some degree, it is. Characterized by its "[. . .] descent into disaster and bondage, which in turn is followed by repentance, then by a rise through deliverance more or less on the level from which the descent began," Grace's story closely follows the rises and falls experienced by a number of Biblical characters (Frye, The Great Code 169). And yet, the introduction of Gnosticism brings an additional element to the text: a liminal - and specifically, a non-canonical -imagination that is, on one hand, more female-oriented; but is also - as I'll explain later - powerfully subversive in the ease with which it foregrounds the heresy of "private," self-contemplative literatures. 
It is interesting to note as I begin here that a similar connection between nineteenthcentury thought and Gnosticism can be found in the aforementioned Etsuko Taketani's 1994 article "Moby Dick: A Gnostic Rewriting of History." Forged from those same concerns, the author provides a context for this subject, expounding on the crisis of faith that was emerging in the United States around the time of the Kinnear-Montgomery murders - a movement Atwood also alludes to with her inclusion of the Jeremiah the peddler character. Of Moby Dick in particular, however, Taketani observes that

Melville's Gnosticism [. . . ] is not so much a product of personal curiosity as it is of American culture's mid-nineteenth century anxieties about the status of Biblical Scriptures. The text of Moby Dick not only reflects the debate over the relation between history, narration, and authority, but contributes its own two-cents to the question. (Taketani 119)

Naturally, I ask: is Atwood following Melville's lead here? It would seem so. She is certainly familiar with Melville and Moby Dick. Another link perhaps is that he wrote for Susanna Moodie's longtime publisher, Richard Bentley. Indeed, one could even say Moodie herself bears a certain role here. Her penchant for embracing new spiritualisms - a trait catalogued extensively by John Thurston in "The Casket of Truth"17 - is, it seems, the inspiration behind some of Grace's own predispositions (her account of the voyage to Canada closely resembles Moodie's own in Roughing (t in the Bush). Like Moodie, Atwood's Grace finds herself exploring faith in terms of what suits her own spiritual needs at that moment. Her departure from orthodox Christianity is suggested early the novel, marked by a realization that "[i]t is shocking how many crimes the Bible contains" (Alias Grace 27). While seemingly a passing comment, the manifestation of its later consequences calls our attention to the same issues that inform Taketani's discussion as well: particularly, 
the complications that arise - and the creative possibilities opened - when the authority of historical narratives, scriptural or otherwise, is questioned.

Taketani tells us that Gnosticism, for all its intrigue, did not seep into the American consciousness out of public curiosity or interest; but rather, arose specifically out of the issue of Scriptural authority; or, as he puts it, "the authority of Christianity as history." It is interesting that the debate itself crested within a year or two of the Kinnear-Montgomery murders; and so, as with other things, Atwood likely presumed this would have been on the minds of the novel's participants. Through Grace - and more importantly, through Jeremiah, who helps to initiate the former into this knowledge - Atwood brings some of those same debates into a larger forum in her novel. The suggestion, we find, is that the same forces which shaped the Bible as historical "text" are those which continue to shape our own Canadian "gospel," particularly with respect to the placement of women within those histories. For his part, Taketani outlines some of the more interesting comments with respec: to the argument as it originally unfolded in the United States; and, in addition to some of the conclusions that were reached, he notes that:

In reviewing Andrew Norton's The Evidences of the Genuineness of the Gospels (1844), the North American Review (July 1844) remarked "Looking only at the character of the events narrated, the history in the Gospels may be only a skillfullycontrived romance" (151). Indeed, when it comes to the relation of history to romance as narrative, real distinction quickly faded from view. The journal observes, "If we [...] look only at the face of the narrative, Robinson Crusoe appears as true a story as Cook's Voyages, and Richardson, the novelist, is as faithful a historian as Hume" (150). The narrative itself, then, has no weight whatsoever" in determining the difference between history and romance.

The question of the relation between history and romance was probably as interesting an issue in the nineteenth century as it is today. "If the gospel narrative is merely a cunningly devised fable or myth," the [North American Review] said, "then we may 
give up history, and throw all such works as the one before us now into the fire." Losing the gospel narrative was tantamount to losing the whole concept of "history" itself. (2)

Here, we begin to get a sense of the reasoning behind the connections Atwood is making between Gnosticism and historical fiction. The questions are the same: if Grace can think of the gospel in terms of a construction, so too might the idea of "history" lose importance: the authority and consequence associated with Biblical narratives would be diminished; and similarly, that narrative would suddenly be open for revision. Just as Taketani reads Melville's Ahab in Moby Dick as an attempt by the former to historicize the Gnostic myth of Creation, so too does Atwood's Grace seem to have the same objective in mind, transmitting experiences that are, by definition, historical, and re-positioning them as a comparable, even superior, myth to the patriarchal forces which have defined her. Like the experiences of her apocryphal counterpart "Susannah," Grace intends to demonstrate that her actions, whether true or not, are ultimately no better or no worse than what can be found in Scripture; and moreover, that this mythic expression is certainly better than the contemporary narratives of the time - such as the newspapers - which continue to misrepresent her.

Atwood was likely attracted to the idea of a Gnostic, or apocryphal, Grace Marks while doing her research for the novel, even hinting as much in her use of the Warden's daybook from the Kingston Penitentiary. Her use of his comment that "[ $[$ ] he convict Grace Marks has been guilty of a double or may I say (Bible) Murder" seems to preface an awareness of biblical parallels that ultimately proves to be Alias Grace's greatest submodality (Alias Grace 418). Given Susanna Moodie's comment also - that the real Grace Marks "[ . . ] looks like a person rather above her humble station" (19) - could Atwood have 
presumed this to imply a superiority of hidden origin? Whatever the case, it is our knowledge of Grace's life, as defined by her own narration, which proves central to the novel's strategy; particularly when one considers that much of those beliefs would certainly be deemed "heresy" by her detractors. In this respect, Grace Marks becomes Atwood's trickster heroine: deceiving - or rather, fooling - those around her in an attempt to save herself and to eventually declare her own autonomy. As an audience, we recognize that both author and protagonist are engaged in some very clever maneuvers: much like Scheherazade, Atwood's Grace is, at once, eager to tell stories - as she does with Simon - but elsewhere, seems to enjoy subverting what Susanna Moodie and her contemporaries once said of her in favor of what she, in turn, might potentially be withholding from them.

Aside from the game itself, Atwood's use of Gnosticism in Alias Grace allows the author to make some rather unique connections. First is the comment that Gnosticism allows on the nature of history and the reliability of memory. Second is that the Gnostic message itself - the idea that salvation can be found by tuming inward - makes room for a variety of additional discussions as well: among them, June Singer's visible and invisible worlds, R.D. Laing's embodied versus unembodied self, and C.G. Jung's portrayals of the unconscious. By trying to encapsulate these and other perspectives within the narrative body, we are not surprised to find Atwood's knowledge of these areas appearing in well-positioned and often humorous forms in the novel. We are given, for instance, Alias Grace's fictive psychologist, Dr. Simon Jordan, whom Atwood intends to "represent the other side of the Victorian attitude toward madness - not the popular, Ophelia-like image, but the body of medical, scientific opinion on the subject" ("Ophelia Has a Lot to Answer For"). There is Susanna 
Moodie as well, resurrected - if peripherally - for her journalistic and dramatic embellishments. Nancy Montgomery and Thomas Kinnear inform a greater Biblical awareness (just as James McDermott does not). And then there is Mrs. Quennel, who would seem to be included in Alias Grace to reflect a growing fascination with mesmerism and the supernatural during the mid-nineteenth century. The Governor's wife seems intended to represent the (female) public's insatiable lust for murder and the grotesque. And finally, Atwood's inclusion of the Reverend Verringer reaffirms the clergy's unwavering - though potentially foolish - belief in the goodness of Grace.

For the remainder of this thesis, I discuss Atwood's use of Gnosticism in greater detail, paying specific attention to her development of a coherent Gnostic myth for each of the novel's invented characters. Looking first at Mary Whitney and Jeremiah the peddler, I explore the position these two characters hold as teachers in the novel: the two who provide Grace with the knowledge by which she successfully reinterprets her this-worldlyperspective. Mary, in particular, is key here. Recalling the Mary commonly known to the Gnostics, her presence is intrinsic to Grace's recognition of new possibilities for the role of women in a patriarchal society: a recognition which leads Grace to the construction of an alternative trinity that best suits her revised views and opinions. Jeremiah too is important here. A traveling salesman and self-proclaimed preacher - one who has recently been in the United States - he represents a geographic/historical transmission of ideas, and the character by whom Grace's already-unorthodox views are further ignited. Together, he and Mary provide her with an opportunity to participate in a belief system that satisfies her own spiritual needs. When looking at Simon Jordan who, we are told, is writing a book on 
criminality, Grace fulfills the Gnostic romance of Simon and Helen, embedding within her narrative the clues by which her true intentions might be read; hoping, it seems, that he might understand and participate in the ideology which has brought her to this point. The Simon and Helen tale is a specifically Gnostic one: in it, Simon, or the Logos idea, assumes the task of rescuing Helen, his First-Thought, from the lower realms. Unfortunately for Atwood's Simon, however, the potential to cultivate that salvation and to fulfill the role of Savior - as Gnosticism instructs - is not easily achieved.

Finally in this paper, I return to Grace Marks herself, exploring how she has developed her own ideology, and why she recognizes that system as heretical - and therefore, by necessity, "private." I am reminded here of Bernice M. Murphy's review of Alias Grace, in which she writes that "this is very much a story about listening, and about reading between the lines in order to get to a truer idea of the real story (Murphy, "Subverting From Within"). In many ways, this seems a fair point from which to begin. Through a series of clever twists and turns, Atwood deftly negotiates the intricacies of larger social trends and movements, while localizing (and mythologizing) those experiences in such a manner that history becomes understood to her audience in terms of the individual. And so, who is "Alias Grace"? She is, one might say, the Grace we can read about historically, only not quite. She is slightly askew from that version: she is the Grace Marks Atwood would like to see; a woman who - as demonstrated by Simon's attempt to capture her in print - cannot be recorded by the "writers-down," for the "writers-down" have failed to recognize that she is constantly changing. Ultimately, our reading of Alias Grace becomes known to us, then, as Margaret Atwood's exploratory - and kinetic - approach to the possibilities of women's lives 
outside canonical "history": an approach which, at once, invites reader participation in the construction of Grace's character, but also appears to safeguard the novel's characterization of the latter within a decidedly specific framework. 
These Teachings Are Strange Ideas:

Reading Mary Whitney 
Grace, [Simon] says [. . . ] who is Mary Whitney?

I give him a quick look. Mary Whitney, Sir? Now where would you get a name such as that? I say.

It is written underneath your portrait, he says. At the front of your Confession. Grace Marks, Alias Mary Whitney.

Oh yes, I say. It is not a good likeness of me.

And Mary Whitney? he says.

Oh, that was just the name I gave, Sir, at the tavern in Lewiston when James McDermott was running away with me. He said I should not give my own name, in case they came looking for us [...].

And did you give any name that came into your head? he says.

Oh no, Sir, I say. Mary Whitney was once a particular friend of mine. She was dead by that time, Sir, and I did not think she would mind it if I used her name. She sometimes lent me her clothing, too.

I stop for a minute, thinking of the right way to explain it.

She was always kind to me, I say; and without her, it would have been a different story entirely. (Atwood, Alias Grace 102).

Girl: When I knot my hands and push my eyes

Back to my dark of skull

I see two faces looming:

One more dim

The mask of a complacent wrinkled

Harridan in mink;

The other nearer

Melting through my teeth of ice

With fire of her hard mouth;

Are these my mother's, sister's, or my own

Pattern in my inevitable bone? (Atwood, "The Triple Goddess")

When Mary [had finished her account], she fell silent, since it was to this point that the Savior had spoken with her. But Andrew answered and said to the brethren, "Say what you (wish to) say about what she has said. I at least do not believe the Savior said this. For certainly these teachings are strange ideas." (The Gospel of Mary, Apocrypha) 
To understand Margaret Atwood's use of Gnostic heresy in Alias Grace, and the function it serves with respect to the feminist arc mentioned earlier, it is useful to first consider her positioning of the fictional character Mary Whitney. Given the knowledge that the name "[...] appears as Grace's alias in the picture that accompanies her confession, but [that] none of the commentators ever mentions a thing about it" (Atwood, Interview), Mary's presence in Alias Grace arrives largely as the product of invention, yet is crucial to the greater Gnostic myth Atwood is creating. As with so many of her novels, Atwood's penchant for literary allusion precedes her here. Readers will recognize in Mary Whitney a composite of many figures; among them, the woman from Sir Walter Scott's "Lady of the Lake"; the pregnant, abandoned maiden in Alfred Lord Tennyson's (similarly-themed) "Charity"; and more notably, the Gnostic Mary of the Apocrypha. ${ }^{18}$ Yet, "I didn't make her up completely," Atwood protests. "My reasoning was that if Grace was going to use an alias, she wouldn't have used 'Whitney' unless she had known some Whitneys" ("Natural Born Quilter'). Consequently, the history she imagines for Mary is a well-crafted one; both of the girl one might expect - a servant of similar age and station to Grace, in whom the latter might confide - and of another, then-contemporary persona, whose life is informed by the lives and experiences of other young women during the period. Of this last point in particular, Atwood explains that

Mary's story and sad end [from a failed abortion] is based on a sad end in a biography of a doctor at the time. An account of the life of a country doctor in mid[nineteenth] century [whose] name was Doctor Langstaff. And he in fact practiced in Richmond Hill, but right after the murders - he didn't know Grace - but there are several cases of girls like [Mary] dying in that fashion [. . . ]. [So] she was based on that, and she was certainly based on lives of servants at the time. 
Given some indication, then, of the literary and historical influences through which Atwood is working, my focus for the remainder of this chapter rests specifically with the relationship Atwood draws between Alias's Mary Whitney and a more Gnostic idea of Mary. To do so is to be reminded that the author's view of history here reflects her unflinching feminist eye, observing historical omission where others would see historical oversight - and this is a crucial distinction to be made. Her awareness that a bridge between the two Marys will be achieved in the novel not on account of the history that is there, but rather, the history that is absent, brings us once again to the processes by which both women found themselves ultimately and/or presumably defined.

Biblically, we are told that Mary is significant in canonical accounts of the nativity only in relation to her son Jesus, but that as soon as her role in his life diminishes, she disappears from those accounts. Similarly, the Bible contains nothing on Mary's life prior to that role, nor does it shed light on her last days and death (Clayton 6). Atwood's awareness of this, and her presumption of similar omissions with respect to the real Mary Whitney (assuming she existed) furthers a parallel embued in Alias Grace between Biblical and Canadian histories as narrative constructions. The attraction to an apocryphal or Gnostic Mary is therefore in the author's best interests here: first, it reflects the marginalized status of women observed in both Christian and Canadian "gospels"; and secondly, it allows through ties to such non-canonical texts as The Gospel of Mary - the literary precedent for Atwood's positioning of Mary Whitney as "teacher" in Alias Grace. Atwood has already pointed to the Apocrypha once before with the novel's inclusion of "Susannah and the Elders." Her addition of a "disreputable" Mary therefore only serves to reinforce that 
"apocrypha" itself

originally meant something 'kept hidden because of its costliness or because of the objectionable nature of its content', then 'of hidden origin' and was a term associated especially with gnosticism. When Christian writers took over the term they associated it with the rejected gnostic texts and used it pejoratively, and by about 400 the word designated texts regarded as disreputable or even heretical, which could not be read in church. (Clayton 7-8)

Margaret Atwood certainly has an affinity for forbidden subjects. Indeed, “[ . . ] it's the very things that aren't mentioned that inspire the most curiosity in us [. . . ," she says; adding that "[t]he lure of the Canadian past, for writers of my generation, has been partly the lure of the unmentionable - the mysterious, the buried, the forgotten, the discarded, the taboo" ("Ophelia Has a Lot to Answer For"). It comes as little surprise, then, that Alias Grace should focus on each of these. The deeper we move into Grace's tale, the more it becomes clear that Thomas Kinnear's explanation of "stories [...] they'd decided should not go in the Bible" is surprisingly apropos (Alias Grace 222). Faced with the potentially incriminating truth surrounding Mary's death [she was apparently made pregnant by the son of her employer, and dies from the after effects of an abortion], and the threat to her own family's "canonicity," the girls' employer, Mrs. Alderman Parkinson, informs Grace: "we will not discuss [the subject] further, as it will only lead to unhappiness and added misery [...] we will not say what Mary died of [. . . ]. That will be best for all" (177-8). And so, like the apocryphal Mary, the life of Mary Whitney - particularly on the days preceding her death is treated in Atwood's novel as a problematic subject: a buried history, because it does not fit within the structure of the canonical history or "gospel." From the author's standpoint, this would have been a more attractive idea than to accept that Mary Whitney's life was 
merely lost or forgotten. And it explains also - as I shall discuss later - the author's positioning of the novel's maidservants as "non-canonical" sisters.

Atwood's displacement of those histories is, of course, not without its historical precedent. Elaine Pagels offers an insightful discussion of this with respect to Gnosticism and history in The Gnostic Gospels (1979), on which Atwood seems to draw. Pagels is important here: like Atwood, she too was a Harvard graduate student, and The Gnostic Gospels was highly acclaimed and well-reviewed when it first appeared. And so, Atwood was likely aware of its existence. Particularly useful here is Pagels's explanation that many of the Gnostics' most sacred texts - among them:

[...] secret gospels, revelations, mystical teachings - are among those not included in the select list that constitutes the New Testament collection. Every one of the secret texts which gnostic groups revered was omitted from the canonical collection, and branded as heretical by those who called themselves orthodox Christians. By the time the process of sorting the various writings ended - probably as late as the year 200 - virtually all the feminine imagery for God had disappeared from orthodox Christian traditions. (Pagels 57)

While the actual reasoning behind these omissions remains unclear - even to the Gnostics - many scholars agree that it was attributable, at least in part, to a correlation between what Pagels identifies as religious theory and social attitudes (60). What Atwood is likely thinking of here, however, is Gnostic schools such as the Valentinians in which women played a greater role with respect to spiritual practice. ${ }^{19}$ Indeed, among the Valentinians in particular, we learn that "[...] women were considered equal to men; some were revered as prophets, others acted as teachers, traveling evangelists, healers, priests, perhaps even bishops [. . .] [whereas] from the year 200, we have no evidence for women taking prophetic, priestly, and episcopal roles among orthodox churches" (60-1). The omission of the feminine from 
orthodox spirituality seems to be the history through which the author is working: indeed, readers will note that the Valentinian roles of "teacher" and "traveling evangelist" are filled in Alias Grace by Mary and Jeremiah, respectively; and furthermore, that this school of thought would seem to fit well with Atwood's apparent use of the Gnostics' Simon and Helen myth, as discussed later in this essay. ${ }^{20}$

For now, Atwood's designation of women's histories as something "unearthed" by historical novelists is - by its very suggestion of recovery - an image to which the author seems intent on returning. To re-assemble those histories in Alias Grace as another (or the "other") Bible is, one might say, the author's primary objective here; in essence, challenging the forces by which "texts" like Grace's and Mary's were originally suppressed. Her use of Gnosticism supports this; in part, because we are told that "since the official Church was patriarchal and authoritarian, Gnosticism gave expression to those matriarchal and libertarian tendencies which are there, suppressed or not, in all societies" (Rexroth xix). ${ }^{21}$ In Alias Grace, the manifestation of those tendencies seems to originate from Grace's recognition that "it was the doctor that killed [Mary] [. . .] him, and the gentlemen [Alderman Parkinson's son] between them" (Alias Grace 178). Mary's death is a physical one, but is also - and more importantly here - a historical one. Indeed, Grace tells us that

the way in which Mary died was hushed up as much as possible. That she had died of a fever may or may not have been believed, but nobody said no to it out loud. Nor did anyone deny that she'd left her things to me, in view of what she had written down; though there were some raised eyebrows at her writing it, as if she'd known ahead of time that she was going to die. (197)

Mary's removal from the official "story" in the Alderman Parkinson home provides Grace with a first-hand understanding of women's lives as "texts"; just as the idea of "prophecy" 
itself - an act strictly forbidden in orthodox churches - also informs her exclusion. How Grace eventually presents that omission, however, is key to how we read Mary Whitney and, ultimately, to how we read Grace herself. Atwood seems to be drawing from the Gnostics here: her inclusion of the apple-prophecy scene (Alias Grace 166) reaffirms the observation that "[a]ll the apocrypha have some details in common," among which is that Mary is told in advance of her death (Clayton 26). Given Thomas Kinnear's placement of the "Susannah and the Elders" tale outside the Bible, it seems appropriate, then, that Grace should choose to reinterpret Mary's life and teachings in a similar fashion: imagining them, Atwood suggests, as non-canonical and - after she meets Jeremiah - specifically Gnostic doctrine. There are two reasons for thinking this: first, the Bible is the only book in Alias Grace that Grace claims to know "backwards and forwards" (222); and secondly, its symbolicallycharged narrative is, conceivably, the only - and perhaps the best - method by which she might communicate those moral and spiritual progressions to Simon.

It is by turning to Mary Whitney's role as "teacher" in Alias Grace, then - and to the novel's first displays of Gnostic tendencies - that one begins to understand the development of Grace's own heretical leanings. To begin, we look to Grace's first recollections of Mary, as told to Simon Jordan. Having lost her mother during the voyage to Canada, Grace recalls that: "I was pleased to be with Mary Whitney, as I liked her at once [. . . ]. She said I might be very young, and as ignorant as an egg, but [felt that] I was bright as a new penny, and the difference between stupid and ignorant was that ignorant could learn" (Alias Grace 147-9). What she learns, however, is central to this thesis: that embracing knowledge - particularly a knowledge of the self; a knowledge of good and evil - is, in itself, not necessarily a bad 
thing. Instead, like Pandora's box, the question is not "why did Pandora open it?" but rather -as Mary says - "why did they leave such a box lying around, if they didn't want it opened?" (146). The relationship Atwood draws toward knowledge in this section of the novel is fascinating: on one hand, Mary's statement connotes what Hans Jonas describes in The Gnostic Religion as "the subjectivist argument of traditional moral skepticism: nothing is naturally good or bad, things in themselves are indifferent [. . . ] [and that] 'only by human opinion are actions good or bad"' (272). Yet, it also imparts a rationalization common to many of the Gnostic sects: a distinction between knowledge and ignorance that many Gnostics equated to the very difference between life and death; salvation and oblivion. It is this idea of saving knowledge which interests me here, primarily for the separation it allows Atwood to form in the novel between mind and body. Under this idea, Grace's physical incarceration becomes less consequential. The author was likely attracted to this because it allows Grace to subvert, spiritually, the freedoms that have been taken from her physically. "Nuns fret not at their convent's narrow room," Wordsworth might say; yet it is useful to preface Mary's involvement in the novel by stating that

[m]any gnostics [. . . ] insisted that ignorance, not sin, is what involved a person in suffering. [And consequently,] the gnostic movement shared certain affinities with contemporary methods of exploring the self through psychotherapeutic techniques. 2 Both gnosticism and psychology value, above all else, knowledge - the selfknowledge which is insight. They agree that, lacking this, a person experiences the sense of being driven by impulses he [or, in this case, she] does not understand [. . .]. [M]ost people live, then, in oblivion - or in contemporary terms, in unconsciousness. Remaining unaware of their own selves, they have 'no root.' (Pagels 124-5)

Here we find that the absence of gnosis or self-knowledge is an obstacle in Gnostic teachings, preventing one from achieving fulfillment; just as the unwillingness to seek out 
knowledge is, in itself, a secondary form of destruction (126). The psychological parallels here are best reserved for my discussion of Simon Jordan, but what is important here is that Atwood's juxtaposition of Grace's physical confinement with the threat of her spiritual confinement reaffirms the necessity for the latter to undertake that journey. ${ }^{23}$

Throughout the novel we become aware - as Grace does (and Simon does not) - that finding gnosis facilitates a transcendence from the trappings of ignorance and suffering that imprison us: that is, we become aware of the beginnings of salvation. The Valentinian school of Gnosticism would say that "what makes us free is the knowledge of who we were, what we have become; where we were, wherein we have been thrown; whereto we speed, wherefrom we are redeemed; [and] what is birth, and what rebirth" (Jonas 334). Atwood presents an awareness of this also. Grace's discussion of the past with Simon, and her inclusion of the aforementioned apple prophecies, illustrates a weighted consideration of those same questions. Given the evidence provided, it seems unlikely that Mary's role in the novel is to specifically pass along Gnostic teachings; rather, it seems more likely that, as a consequence of hindsight and narration, Atwood's Grace has chosen to cast her memory of Mary's philosophy in a decidedly Gnostic light - largely, it seems, on account of what Jeremiah the peddler had since taught her. And so, although somewhat indirectly, Mary's observations of their lives as servants has assisted Grace in understanding -in a very Gnostic sense - a broad range of issues; among them: the fallen state of the world, the circumstances which have defined her situation, and the means by which she might escape them both. And yet, while the path itself is initially set out for her by the novel's "teachers," it is a journey that Grace must ultimately take alone. 
During her time with Mary Whitney, Grace finds herself exposed to knowledge that she had neither known nor previously considered. "Mary took me under her wing from the very first [. . .]," she explains to Simon. "I was to be made presentable [. . .]. But first I [had to] be scrubbed like a potato, I was that filthy" (Alias Grace 151). This notion of cleansing Grace becomes important later on; but what is prescient here, while speaking to Simon of hers and Mary's relationship, is one lesson in particular from her companion's teachings specifically, Mary's belief that

[. . . being a servant was like anything else, there was a knack to it which many never learnt, and it was all in the way of looking at it. For instance, we'd always been told to use the back stairs, in order to keep out of the way of the family, but in truth it was the other way around: the front stairs were there so that the family would keep out of our way. They could go traipsing up and down the stairs in their fancy clothes and trinkets, which the real work of the place went on behind their backs, without them getting snarled up in it, and interfering [. . . making a nuisance of themselves. They were feeble and ignorant creatures, although rich, and most of them could not light a fire if their toes were freezing off, because they didn't know how [...] [or that] if they were to lose all their money tomorrow and be thrown out on the streets, they would not even be able to make a living by honest whoring [...]. (Alias Grace 158)

There are two things going on here: first is notion that the truth of one's circumstances is "all in the way of looking at it"; the larger implication being, of course, the possibility of reading outside traditional boundaries. Second here is Mary's identification of the Alderman Parkinsons as "feeble" and "ignorant": a distinction that seems, on one hand, a contempt for those of higher class or station, but is also, suggestively, later read by Grace as a reinforcement of the gulf between those with gnosis and those without. This becomes important when later considering Grace's relationship with the apple of knowledge and, particularly, with Atwood's suggestion of the true motives behind those who have 
imprisoned her. Of Mary's proposal that it's "all in the way of looking at it," however, we find a playful, but crucial perspective for Grace at this point in the novel. While the message itself may appear elementary in light of her later conclusions, she wastes little time in finding uses for its application.

One such moment in the novel comes as the girls decide to delay their retum to the Alderman Parkinson home one day so that Grace might view "the women who made a living by selling their bodies" (152). What is crucial about this scene in particular is not the concept of prostitution itself (although this is important to the novel's reflection of women's histories); rather, it is the manner by which Grace evaluates what is shown to her, noting that although they might look very elegant from a distance, with feather and satins, up close you could see that their dresses were soiled and ill-fitting, as every stitch on their backs was rented by the day, and they scarcely had enough left over for their bread; and it was a dismal sort of life, and [Mary] wondered why they did not throw themselves into the lake, which some did, and were often found floating in the harbour. (152-3)

Grace's view of the prostitutes moves beyond facades or cosmetic attributes to assume a more practical sensibility, concentrating not on the occupation itself, but on the hardships they face as women. In many ways, Atwood is using the scene to preface Grace's later disillusionment with orthodox Christianity. Mary does teach Grace in this section of the novel that the idea of "Eve's curse [.. .] was stupid, and that the real curse of Eve was having to put up with the nonsense of Adam, who as soon as there was any trouble, blamed it all on her" (164) - reminding us again of the abuse and displacement of women's histories within Biblical structures. Much like the religious and moral hypocrisy Grace finds elsewhere in the novel, the most important lesson she learns from Mary Whitney here is how to view 
alternate interpretations of the visible world: an idea originally presented in relation to their roles as servants, but is taken further by Grace as a key to viewing the world for its cruelty to women. This is, of course, important to Grace when later solidifying her own ideology, and so Mary's role in Alias Grace does seem instrumental to this, but is established in a very indirect way. "Mary was an outspoken young woman," is how she explains it to Simon, "[. .. ] and she had very democratic ideas, which is took me some getting used to" (159). And yet, readers recognize that it is much more than this. Instances such as Mary's playful mockery of authority in the novel, and Grace's observation that "[Mary] prayed so much because she was praying to God to get her white teeth back again, but so far no results" (148) are retold to Simon here in terms that suggest not that Mary was trying to make the best of a difficult life, but that it was she in particular who led Grace - whether knowingly or not to a loss of faith in the Father.

Even with this, however, Atwood remains playful. "One father leads to another," Simon Jordan tells us (140). And indeed, this idea of new readings, and new possibilities in Alias Grace is best evidenced in the novel through Grace's revision of the Holy Trinity to favor a more Gnostic, matriarchal relationship. By this point, Atwood has already established Grace's father in the novel as a wicked, hateful tyrant who maltreats his children - one who bears strong similarities to the cruel Jehovah or Old Testament Demiurge. The reader will notice that Atwood is working on a couple of levels here: first, it is an account of Grace's relationship with her father, and secondly, it draws an allegorical relationship between man/patriarchy and God the Father. Initially, Grace bewilderedly recalls a time in which "[she] was still trying to please him" (108), yet subsequently professes to Simon her 
moral qualm that "[. . . ] it is not right to speak ill of a parent" (149). What follows, however, is a narrative maneuver which delivers yet another upset, given the novel's more orthodox environment. I am referring here to one of Grace's final discussions about her father; and particularly, her confession that

I believe it was only [after my mother's death] that I truly began to hate him, especially considering how he had treated our mother in life [. . . . The older I became, the less I was able to please him, and I myself had lost all of a child's natural faith in a parent, as he was drinking up the bread out of his children's mouths, and soon he would force us to begging, or thieving, or worse. Also his rages returned, stronger than before my mother had died. Already my arms were black and blue, and then one night he threw me against the wall, as he'd sometimes done with my mother, shouting that I was a slut and a whore, and I fainted; and after that I feared he might someday break my spine, and make a cripple out of me. (129)

Atwood is being clever here, playing with Gnostic patterns: the father-daughter relationship described above essentially repeats the Gnostic theme of the Son rebelling against the Father; one best evidenced in the writings of William Blake. In particular, Atwood seems to be drawing from Blake's Urizen: the "cruel father of children." First seen in The Book of Urizen (1794), and again in Vala; or, The Four Zoas, the significance of Blake's work here is that it is representative of a late eighteenth-century movement of the Romantics back toward the Genesis creation myth. Blake's reading of Genesis in particular is one that has been tied with Orphic (second century Gnostic) teachings: A.D. Nuttal's The Altermative Trinity, for example, makes this point clear, noting the similarities between Gnostic thought and cosmologies laid out by Blake (10). Through a similar maneuver, Atwood seems to be furthering a Gnostic tradition of sorts by shifting the focus to the daughter (Nuttal 11). The importance of this joumey back to the original Creation myth becomes clear in my later 
discussion of Grace Marks; but, suffice to say, the attraction for Atwood here is that God represents - as He likely did for Blake - the Original Patriarch.

Presumably led by the Romantics' tendency to upset the structure of order in their narratives, Atwood's novel arrives at the same reversal: God the loving Father in Christianity becomes God the oppressive tyrant in Alias Grace. Ihave noted that it is common in Blake's writings, and others - such as Mary Shelley's Frankenstein, where Frankenstein betrays his creator - use it as well. In Alias Grace, these same ideas reappear. Certainly, one could argue that this was merely a limited movement among the Romantics; or, that many of these writers were, in fact, working independently of any knowledge of Gnosticism. Yet, ultimately - and the same may be true here for Atwood as well - "whether [these] writers [. . .] worked from models or shaped their creation myths independently, the fact is that their myths take a gnostic turn" (Cantor xi). Margaret Atwood, in particular, seems to enjoy complicating Biblical structures: indeed, Mary Whitney and Grace's Gnostic Trinity comprised of Grace, Mary, and Nancy - seems to represent a return of sorts to the origins of canonical history - the original Creation myth; for what better way to (re-)inscribe the role of the feminine in the Gospel narratives than to start at the beginning. The author recognizes here that if God and the Son (or in Alias Grace, the Daughter) do not stand together, or stand in opposition, the triad itself cannot exist in unity. And so, the Trinity she imagines for Grace is one constructed not from a patriarchal-based relationship, but from a union of women's histories identified in the novel. In doing so, Grace's and Atwood's attempts to reclaim the God in Three Persons becomes highly subversive to those systems, for hers is a 
trinity in which the masculine principle is forsaken for a structure in which all parts are feminine and, presumably, equal.

It would appear from closer examination of Grace's narrative that she is not exposed to this perspective from her mother, presumably because the latter is described by Grace as "weak-spirited"; unable to claim her independence from the father (Alias Grace 109). And so, as I've said, bringing Grace Marks to this point, although perhaps somewhat unwittingly, is Mary Whitney. Her offer to help Grace rid herself of her father's rage is accepted by Grace shortly after her entry into the Alderman Parkinson home. Indeed, Mary encourages her that they should battle the cruel father together; and of this scene in particular, Grace recounts to Simon that:

My father came round at the end of the first month, and wanted all my wages; but I could only give him a quarter, having spent the rest. And then he began to curse and swear, and seized me by the arm; but Mary set the stablehands onto him. And he came back at the end of the second month, and I gave him a quarter again, and Mary told him he wasn't to come any more. And he called her hard names, and she called him worse, and whistled for the men; and so he was chased off. (Alias Grace 157)

Here, Grace's father is removed from the picture. Given the novel's technique or penchant for correspondences between the visible/invisible worlds, Atwood's text can be read here to suggest not only the spiritual (orthodox) Father, but the lower Father as well.

Initially, the structure of the Trinity left behind is uncertain: Grace no longer feels love for the Father - now, the Gnostics' Demiurge, or inferior God - and, presumably, realigns herself with the Unknown God (Forefather) who exists beyond the visible world. Indeed, "God is everywhere," she acknowledges, "and cannot be caged in, as men can" (254); doubly referring to both physical incarceration, and man's suffering at the center of 
the Gnostics' "outer darkness." It is not surprising, then, when Grace's abandonment of her father (or the Father) in Alias Grace comes with little guilt or remorse over her actions. The suggestion, we read, is that

[w] hether one pictures the creator-god as malevolent, or as simply mistaken as to how to make man happy, or perhaps just incompetent in carrying out basically good intentions, the liberating effect of these gnostic visions of the creator is the same. Man need no longer be in awe of his creator; he need no longer even feel grateful for being created. He can turn his back on God with a good conscience and set about charting his own course, seeking out ways to remake an imperfectly created world, and even to change his own nature for the better. The denigration of God as a creator in Romantic myth is for the sake of exalting man's own creative potential. (Cantor xiv)

And this is precisely what Grace hopes to accomplish. The abandonment of the Demiurge or creator-god can only, in her eyes, be viewed as a good thing. By approaching the world around her - a place already identified as cruelly unkind to women - Grace seeks to make an improvement in her circumstances by fulfilling the virtues of her own nature, and by aligning herself with a still higher, unknown force.

What we find in place of the orthodox Trinity by novel's end is a continuation of this idea: a makeshift replacement that is, in essence, a reconstituted Trinity; one in which both Mary Whitney and Nancy Montgomery have assumed a role. In describing the quilt pattern itself, the Tree of Paradise - and her knowledge that this is a structure best concealed within a larger frame - Grace explains that

[...] three of the triangles in my Tree will be different. One will be white, from the petticoat I still have that was Mary Whitney's; one will be faded yellowish, from the prison nightdress I begged to keep as a keepsake when I left there. And the third will be pale cotton, a pink and white floral, cut from the dress of Nancy's that she had one the first day I was at Mr. Kinnear's, and that I wore on the ferry to Lewiston, when I was running away. 
I will embroider around each one of them with red-feather stitching, to blend them in as a part of the pattern.

And so we will all be together. (Alias Grace 460)

Certainly, this image of the Trinity brings with a host of associated patterns found throughout both Gnostic and Christian literatures; among them, the idea of God the mother; or, the Father, Mother, and Holy Spirit; or perhaps it is something altogether different. What is more important here, however, seems to be the role that Mary assumes with Grace and Nancy as supporters of their structure. Aside from Grace's observation that "[Nancy] resembled Mary Whitney" (202), and that she "[. . .] laughed and joked much as Mary Whitney had done" (200), the cohesion of that unit is perhaps accounted for when Grace comments much as Mary had does before her - that "Nancy [said] [. . . ] you had to learn to stand up for yourself in this life; and I thought that was true" (201).

Throughout Alias Grace, Mary Whitney's role as a teacher of new knowledge is one paralleled by the Gnostic text The Gospel of Mary, which Atwood seems to know. In it, Mary attempts to realize her role as a disciple of Christ despite the objections of patriarchal forces; particularly those belonging to more orthodox leaders. Gathered with the other disciples, the tract details how she encounters hostility and disbelief after disclosing what she claims the Savior taught her privately, through thought. Following an argument questioning her right to preach the gospel, the Savior intervenes, saying that whoever the Spirit inhabits may be able to speak, man or woman:

[...] Mary stood up, greeted them all, and said to her brethren [.. .]. 'What is hidden from you I will proclaim to you.' And she began to speak to them these words: ' $\mathrm{T}$, she said, "I saw the Lord in a vision and I said to him [ . . . Lord, [. . . ] how does he who sees the vision see it (through) the soul (or) through the spirit?' The Savior answered and said 'He does not see through the soul nor through the spirit, but the 
mind which is between the two [.. . ] that is what sees the vision. (The Gospel of Mary 472)

[w] hen Mary had [finished speaking] she fell silent, since it was to this point that the Savior had spoken with her. But Andrew answered and said to the brethren, 'Say what you (wish to) say about what she has said. I at least do not believe that the Savior said this. For certainly these teachings are strange ideas.' Peter answered and spoke concerning these same things. He questioned them about the Savior: 'Did he really speak privately with a woman (and) not openly to us? Are we to turn about and all listen to her? Did he prefer her to us?' (473)

And so, The Gospel of Mary seems to inform Atwood's Mary Whitney, both in the outspokenness she exhibits and the emphasis on mental faculties as the medium for divine revelation. I am reminded here by Nancy's and Mary's belief that a woman has to stand up for herself; and indeed, it is conceivable that Atwood is drawing from The Gospel of Mary here because it also makes this connection. Mary's life - particularly the teachings she imparted - is absorbed by Grace in the novel much as she would absorb the revelations within a text. "[. . .] [ ] $\mathrm{t}$ was her name I borrowed, when I was in need of it," she says, "for she was never one to refuse a friend in need, and I hope I stood by her well, when the time came for it" (Alias Grace 147). Even the ballad "The Lady of the Lake" is well-positioned here: Atwood reverses the expectations set up by Sir Walter Scott's tale of the seduced and abandoned maiden, concentrating instead on Grace's recognition that "' 'was the truth in her eye ever dawning, That made me love Mary, the Rose of Tralee" (170).

And yet, what is this truth? We might read this as an extension of Mary Whitney's earlier belief that "it's all in the way of looking at it": the Gnostic's penchant for reading histories differently; or of seeing beyond the visible world. But perhaps the greatest of Mary's teachings in Alias Grace - and certainly one which becomes important to Atwood's 
murderess later in the novel - is the need to perform one's duties as one wishes but, above all, to do so without being seen. If a woman and - more specifically - a servant, is successful in this, Mary says, those of her kind will reach a unique conclusion about their place in the world: specifically, that "[i]n the end, we had the better of them, because we washed their dirty linen and therefore we knew a good deal about them; but they did not wash ours, and knew nothing about us at all" (158). What Atwood is really speaking about in this image of dirty linen, however, is secret or hidden knowledge. 
III

"Jeremiah, Blow the Fire":

Raising the Divine Spark in Alias Grace 
I sold [Mary's] box, which was good quality, and also her best dress, to Jeremiah the peddler, who came around again just after her death; and I also sold him the gold ring which she kept hidden under the floor. I told him it was to pay for a decent burial, and he gave me a fair price and more. He said he'd seen death in Mary's face, but then, hindsight is always accurate. He also said he fett sorry for her death, and would say a prayer for her, although what sort of prayer I could not imagine, as he was a heathenish sort of man, with all his tricks and fortune-telling. But surely the form of a prayer does not matter, and the only distinction God makes is between good will and ill; or so I have come to believe. (Alias Grace 198) 
Our first introduction to Jeremiah the peddler in Alias Grace comes as a rather playful moment in the novel, yet is surprisingly indicative of greater things to come. Observing a procession of children following a man down the street, Grace notes both the event and the accompanying song: "Jeremiah, blow the fire / Puff puff puff; / First you blow it gently, / Then you blow it rough!" (Alias Grace 153). Although his appearance at this point in the novel precedes the death of Mary Whitney, it isn't until later that Grace discovers that the ideas he holds are in fact closely united with the former's; and that when placed under the banner of Gnosticism, Mary and Jeremiah's teachings assume a more distinct and heretical shape. Indeed, it is Mary and Jeremiah who allow Atwood to sustain the novel's Gnostic undercurrent. If one reads the song above as indicative of the novel's larger structure, it is easy to understand the metaphor through which the author is working: the flame or divine spark of gnosis as previously lit by Mary Whitney - while once small and indefinite - is, on account of Jeremiah, made fiery and apparent here from the benefit of his teachings.

As with her other invented persons, Atwood grounds the function of Jeremiah's character in the novel as a conflation of Gnostic elements. On one hand, it seems she is using Jeremiah the peddler here as a form of "World-savior," as commonly associated with the Saturninus school of Gnosticism. Theirs is a concept that emphasizes regeneration, "whereby a World savior in the form of a man, though not really a man, brings about not only the defeat of evil powers, but also rescues all who have the light spark within them" (Mead 179). Teaching also the greater, Unknown Father, and many of the same ideas about gnosis mentioned earlier, Saturninus' approach to redeeming the spiritual elite is in keeping with 
many of the novel's other Gnostic tendencies. Indeed, the World-savior image itself holds a close association to the Simonian myth of Simon and Helen, which is also important here. As I explain in the proceeding chapters, the relationship Atwood draws between Grace Marks and the novel's psychologist, Dr. Simon Jordan, appears to be firmly grounded in this myth, and the redemption of Grace Marks, if in fact the novel wishes one, ultimately seems dependent - at least in part - on the success of that union.

My emphasis for now, however, rests with the presence of a somewhat darker element in Atwood's Jeremiah. The more orthodox members of Atwood's community frequently refer to him in the novel as Devil-like or untrustworthy (Alias Grace 154-5, 269); and Grace herself concedes at one point that although Jeremiah seemed kindly, "[. . .] appearances can be deceptive, as [Mary] found to her cost" (268). Ironically, some of the Gnostic undertones identified in Paradise Lost, or even Marlowe's Dr. Faustus (Nuttal) and which define the "tempter" in those works - are the same qualities operating in the relationship between Grace Marks and Jeremiah the peddler. This is not to say or imply that there are Gnostic undertones in all works; or that this is common by any means; but rather, that many works can be read through, or bear similarities to in their systems of thought, a Gnostic framework. I will return to this shortly, but suffice to say that Atwood does so here, presumably, to illustrate the contrast in public reception: the Gnostic ideology, while heretical and foreboding to some, is for others the only true path to salvation. Historically, Jeremiah's presence in Alias Grace can be attributed to a number of factors. Most visible, however, is the function of his occupation itself: Grace informs us that - among other things - Jeremiah is a peddler; that he imports foreign and exotic items from elsewhere so they can 
be bought and sold in the colonies. Among those goods, however, is Atwood's suggestion that what Jeremiah really peddles here is knowledge.

The allusion is a complex one, but it is one which deserves to be worked through. We are told, for instance, that Jeremiah the peddler is an American (154). Recounting his recent travels, he informs Grace: "I was lately down in the States where I can buy notions cheap, and sell them up here for more [. . .]" (266). What comes to the reader's mind perhaps first here is the author's double use of "notions" as both goods and ideas. Furthermore - and more importantly, however - those familiar with what was occurring in the United States around the time of the Kinnear-Montgomery murders will also recognize that - at the same time as the authority of Scripture was being questioned - one could also find a rapidly growing fascination with Gnosticism. Indeed, Etsuko Taketani tells us that

the United States in the early nineteenth century was much more active about learning about Gnosticism than we usually imagine. Norton's The Evidences of the Genuineness of the Gospels (1844) was the first scholarly book of Gnosticism ever produced by an American. Despite the fact that it was written to confirm the genuineness of the Gospels, this was an amazingly extensive book covering all imaginable topics on Gnosticism, including chapters "On the System of the Gnostics, as intended for a Solution on the Existence of Evil in the World," "On the Opinions of the Gnostics concerning the Evil as inherent in Matter," and "On the Opinions of the Gnostics concerning the person of Christ." (Taketani)

Is Atwood using Jeremiah in Alias Grace as a transmitter of these ideas, then? It would seem so, particularly given his later teachings. Indeed, when commenting on the subject of religion, he acknowledges:

I could become a preacher [. . . ]. Below the border there is a great demand for it, more so than here, in particular during the summers, when the preaching is done outdoors, or in tents; and the people there love to fall down in fits, and talk in tongues, and be saved once a summer, or more if available [...]. A faithless preacher 
with a good manner and voice will always convert more than a limp-handed longfaced fool, no matter how Godly [. . .]. (Alias Grace 267)

Admittedly, Jeremiah's intent here is to make money under false pretenses. Atwood may be speaking from a Canadian nationalist perspective here, offering a specific comment or barb on U.S. religiosity; however, she is, I think, more broadly hinting toward the novel's underlying implications of religious and moral hypocrisy in orthodox practices. Certainly, Jeremiah's views here precede similar offerings by Grace in the novel (253-4); and moreover, Grace's predilection for trickster narratives also seems to owe its origin to the techniques and advice offered within these passages..

All of this brings me back to an earlier point: which is that - aside from the offer of forbidden knowledge - Margaret Atwood is playing with something else too. Grace's repeated description of Jeremiah's "piercing" (154) and "shining" (155) black eyes and even more subtly - a trick in which "[. . . ] he could swallow a fork, or appear to" (the suggestion being, of course, a forked-tongue), finds the author emphasizing Jeremiah's role as the serpent-tempter of both orthodox and unorthodox religion. The significance here lies in the differences of reception with this figure. Orthodox Christianity views the serpent as He who led Adam and Eve to the Fall by exposing them to the Tree of Knowledge; and indeed, this would account for the suspicious attitudes toward Jeremiah by the novel's more pious characters (154-5; 269-70). Not so in Gnosticism. Indeed, citing some of Hans Jonas' views of Gnostic dualism, Stefan Rossbach tells us:

[.. . ] The snake is here a representative of the divine sphere, who reveals to humans the evil purposes of their creators. They want to keep Adam from eating the forbidden fruit only in order to preserve his state of ignorance. Adam, of course, eats from the forbidden fruit and thereby obtains knowledge, gnosis, of his divinity. Full 
of envy and anger, the archons expel Adam and Eve from paradise and send them to earth. Witnessing the spark of light glowing in Adam, they become fully aware of his superiority and decide to make him forever a prisoner of matter. They curse Adam and Eve and everything that exists in the cosmos. The demiurge and the archons remain masters of the matter, hyle, and the cosmos, but the divine plan to overcome creation and hence to deprive them of their power now has powerful assistants in the men and women of knowledge.

The episode which places humanity above its creator is essentially an inversion of the Christian reading of Genesis. Adam actually obtains knowledge by eating the forbidden fruit. This act is an act of liberation, of awareness, of awaking from the sleep of ignorance. Eating the fruit was humanity's first revolution against the oppressive creators, the beginning of its emancipation. Through knowledge, humans realize that they have to turn away from their creators. In this outlook, the Christian exegesis appears as the continuation of the archonic attempt to keep humans in a state of ignorance about their real powers. (Rossbach 51-2)

This would seem to account for much of Grace's actions and beliefs discussed later in this essay. Moreover, the influence that Mary Whitney has already had on Grace becomes clear, given the movement discussed in the above passage; and it gives some indication also as to the direction she will take with Jeremiah through his teachings.

Jeremiah's function within the Gnostic perspective - while crucial to Grace's later ideology - does not actually occur in the novel until considerable time has passed in their acquaintance. Instead, we find that the origin of their relationship is fraught with Gnostic innuendo - as though she is being tested - during which time Jeremiah informs Grace "you are one of us" (Alias Grace 155). Naturally, one can read this a number of different ways, just as Grace also professes its ambiguity to Simon. It could be that Jeremiah views Grace as a wanderer of sorts, like himself: this much is assumed by her. Taken more liberally, however-particularly if one considers Grace's narration after-the-fact-it seems more likely here that he is referring to Grace as having an elevated potential for gnosis. Whichever the case, the point is that Jeremiah provides the latter with the means to understand her place in 
the Kinnear-Montgomery household. Telling Grace of his travels around North America, Grace recalls one of the more subversive sermons he gave:

Laws are meant to be broken, he said, and these laws were not made by me and mine, but by the powers that be, and for their own profit. But I am harming no one. A man with any spirit in him likes a challenge, and to outwit others; and as to being caught, I'm an old fox, and have been at it a few too many years for that. (266)

Are the "powers that be" Jeremiah is referring to here actually the Gnostics' archons, intent on keeping mankind in a state of ignorance? Is the "spirit" within him actually the divine spark espoused so readily in Gnosticism? Certainly, these are intriguing possibilities. But his statement that "Laws are meant to be broken" is of primary importance here, for it is assumed that - when coupled with Mary Whitney's earlier statements - she might be freed from the trappings of conventional morality.

In this manner, Atwood's model for Jeremiah may in fact by the Gnostic teacher Marcus. - who, we are told, was well-known for his abilities to draw women away from orthodox churches and into heretical groups. In The Gnostic Gospels, Elaine Pagels describes him as

[...] a diabolically clever seducer, a magician who compounded special aphrodisiacs to "deceive, victimize and defile" his prey [. . .]. Marcus "addresses them in such seductive words" as his prayers to Grace, "She who is before all things, "and to Wisdom and Silence, the feminine element of the divine being. Second [...] Marcus seduced women by "telling them to prophecy" which they were strictly forbidden to do in orthodox church. (Pagels 59)

There are two things of importance here in relation to the novel: first is Jeremiah's suggestion to Grace that she could run away with him and be his partner in a medical clairvoyance scheme, which on one hand seems to further this idea of the Marcus relationship: the Gnostic teacher seducing the "foolish woman"; and secondly, parallels 
Marcus's invitation to women "to act as priests in celebrating the eucharist with him" (5960). When speaking to Simon of Jeremiah's offer, she states: "I won't conceal from you, Sir, that the idea [to leave with him] was greatly tempting" (Alias Grace 268). Beyond this, however, is the second point here: Jeremiah's own knowledge of prophecy, who wisely explains to Grace that "[t]he future lies hid in the present, for those who can read it" (265). The point Atwood seems to be making here is that Jeremiah is responsible for Grace's final departure from orthodox teachings; threatening to the Victorians because her invited role as "teacher" or "prophet" assigns her a specifically masculine function. He provides a bridge of sorts - as evidenced by the aliases "Jerome DuPont" and "Gerald Bridges" - between traditional doctrine and an awareness of gnosis or saving knowledge. He is indeed the World-savior: either working alone, or in tandem with Grace. He defeats the archons - the lower powers who wish to keep her imprisoned - by using trickery, and clears the obstacles for her so that she may cross Jordan. If we read his own accounts of his Mesmerism and Magnetism cons, also performed with a woman, we find an apt explanation as to the success of both ventures. Here, he tells us,

I was the one who made the passes and took in the money, and she was the one to have a muslin veil put over her, and go into a trance, and speak in a hollow voice, and tell the people what was wrong with them, for a fee of course. It is wellnigh foolproof, for as they can't see inside their own bodies, who's to say whether you're right or not. (267)

Atwood, of course, has a double meaning here: Jeremiah's statement is a barb at the public's lack of knowledge; but more importantly, mocks their lack of self-knowledge as well. For what's inside their own bodies, he suggests, is an unrealized Gnostic potential that they have yet to awaken. 
The final scene in the novel in which we see an interaction between Jeremiah and Grace arrives after she has begun her new life with her husband, Jamie Walsh. Now presumably in Paradise, she observes that Jeremiah is again presenting himself to the public as a medium, and when passing him on the street she notes that he "[. . . was more elegantly dressed than ever [. . .] doing a very good imitation of a man who is distinguished and at home in the world, but with his mind on the higher truth" (456). What is significant about the culmination of this relationship, however, is the implications it ultimately raises for morality. Specifically, Hans Jonas tells us that "in this life

the pneumatics, as the possessors of gnosis called themselves, are set apart from the great mass of mankind. The immediate illumination is not only makes the individual sovereign in the sphere of knowledge (hence the limitless variety of gnostic doctrines) but also determines the sphere of action. Generally speaking, the pneumatic morality is determined by hostility toward the world and contempt for all mundane ties. From this principle, however, two contrary conclusions could be drawn, and both found their extreme representatives: the ascetic and the libertine. The former deduces from the possession of gnosis the obligation to avoid further contamination by the world and therefore to reduce contact with it to a minimum; the latter derives from the same possession the privilege of absolute freedom [...]. The law of "Thou shalt" and "Thou shalt not" promulgated by the Creator is just one more form of "cosmic" tyranny. The sanctions attaching to its transgression can affect only the body and the psyche. (46)

This is a nice lead-in to my discussion of Simon Jordan, but what is significant about Jonas's statement here is the freedom through which Jeremiah and Grace Marks - the novel's suggested possessors of gnosis - presently enjoy the rewards of their "good deeds." What is also significant about this "pneumatic morality," however, is that one senses the superiority of their own hand; and the contempt for those around them. Atwood's Grace is very subtle in this regard: of the prison guards who taunt her, for example, she deems their sexual jokes as belonging to "a low class of person" (Alias Grace 64); and later, as the 
congregation looks in judgment upon Nancy Montgomery for her relationship with Thomas Kinnear, Grace notes:

"[t]hese are cold and proud people, and not good neighbours. They are hypocrites, they think the church is a cage to keep God in, so he will stay locked up there and not go wandering about the earth during the week, poking his nose into their business, and looking into the depths and darkness and doubleness of their hearts, and their lack of true charity. (254)

And yet ironically, despite the contempt she shows toward those around her, we as readers are ultimately left with the unsettling recognition that - just as Simon must place his trust in Grace's narrative - we too must do the same. Given that both Grace and Jeremiah have revealed themselves to be proponents of trickery en masse, the novel itself is very selfreflexive on this point. "Perhaps I will tell you lies," Grace cautions Simon in one of their earliest sessions (41); but the reader knows, as Simon does, that " $[\mathrm{w}] \mathrm{e}$ will just have to take that chance." 
Failing the Gnosis Test:

Simon Jordan and the Gnostic Potential 
He must be careful, he tells himself. He must draw back. Looked at objectively, what's been going on between them, despite her evident anxiety over the murders and her surface compliance, has been a contest of wills. She hasn't refused to talk - far from it. She's told him a great deal; but she's told him only what she's chosen to tell. What he wants is what she refuses to tell; what she chooses perhaps not even to know. Knowledge of guilt, or else of innocence: either could be concealed. But he'll pry it out of her yet. He's got the hook in her mouth, but can he pull her out? Up, out of the abyss, up to the light. Out of the deep blue sea.

He wonders why he's thinking in such drastic terms. He means her well, he tells himself. He thinks of it as a rescue, surely he does.

But does she? If she has anything to hide, she may want to stay in the water, in the dark, in her element. She may be afraid that she won't be able to breathe, otherwise.

Simon tells himself to stop being so extreme and histrionic. It may well be that Grace is a true amnesiac. Or simply contrary. Or simply guilty.

She could, of course, be insane, with the astonishingly devious plausibility of the experienced maniac. Some of her memories, especially those of the day of the murders, would suggest a fanaticism of the religious variety. (Atwood, Alias Grace 322) 
I have noted earlier that in her use of Gnostic myth in Alias Grace, Margaret Atwood has displayed a broad knowledge of discussions uniting psychological theory and spiritual practice. I have broached also the heretical teachings of Mary Whitney and Jeremiah the peddler in the novel, explaining their significance in relation to the novel's myth-asnarrative-strategy arc. Having been conscious of those relationships, it is in a similar vein that Atwood's inclusion of the fictive Simon Jordan effectively maps a space between the clinical and the Gnostic - in doing so, challenging the science by which the unknown self is purported to be understood, but satisfying also what readers recognize as Grace's individuation. He is also found in the Simon and Helen myth known to the Gnostics as the figure of Simon Magus, sent to rescue Helen, his Thought, from the depths of chaos. Initially, Atwood's effort to use this space informs a familiarity with what was occurting historically: "interest in aberrant states of mind, and in the workings of the psyche," she writes, "was intense during the whole of the nineteenth century" ("Ophelia Has a Lot to Answer For"). Additionally however, Alias's use of theory engenders other questions pertaining to that larger, collective memory known as "history." The connection may not immediately become apparent, yet the processes, Atwood notes, are the same. "For history, as for the individual," she says, "forgetting can be just as convenient as remembering [...]. As a rule, we tend to remember the awful things done to us and to forget the awful things we did" ("In Search of Alias Grace" 1505). The novel's attempt to encapsulate this and to show - at least in part - that Grace too may be the victim of memory's selective nature, reminds us that much of what we think we know is often the product of the faith we place in those accounts. 
In Atwood's fiction however, memory is also design; and for the purpose of my discussion here, this is the area in which I wish to direct the most focus; for "what is told by [Grace] to an audience of one, Dr. Simon Jordan [. . .] is selective," the author tells us. Mostly, "[. . .] it is dependent on what she remembers [. . .] or is it what she says she remembers [. . .]? And how can her audience tell the difference?" (1515). Having established earlier that an individual's memory is shaped as much by the act of forgetting as it is one's willingness to forget, the reader comes to recognize, just as Simon does, that often it is necessary to take that chance (Alias Grace 41). For her part, Atwood enjoys playing with uncertainty. Focusing largely on what we know of the "self" or unconscious as keeper of those events, characters such as Simon Jordan bring to the novel questions which are still highly pertinent, for "what is the self - the 'character' - without a more-or-less continuous memory of itself," Atwood asks; "what is the novel without the self?" ("In Search of Alias Grace" 1506). In his view, the studies this would entail become central to the progress of the human condition; and "the nineteenth century, he concluded, would be to the study of Mind what the eighteenth had been to the study of Matter - an Age of Enlightenment [...]. He was proud to be part of such a major advance in knowledge, if only in a very small and humble way" (Alias Grace 300).

So, how do we, as readers, negotiate our path through all of this? On one hand, we could say that Atwood is simply being historical here, mirroring crises of faith that were taking place in both Canada and the United States at the time of the murders. Certainly her awareness of anxieties forming toward issues such as madness and psychoanalytic theories - not to mention a general uncertainty toward matters of Scripture - offered her the 
opportunity to display her knowledge of those fields. Alternatively, however, we find in those debates a heightened potential for fiction, for what better to challenge one's knowledge of the self or unconscious than to approach it from very different perspectives. Simon's faith in reason, or in the measurable and deductible - embodied here as medical opinion - stands in stark contrast to what Atwood presents as Grace's hopes for a Gnostic redemption, just as the novel's inclusion of Reverend Verringer, Mrs. Quennell, and Susanna Moodie also serves specific functions. Ironically, Simon the psychologist's task is the same. Both he and the Gnostic attempt to answer the mysteries of the universe in his or her own way, as do those who might follow Magnetism, Mesmerism, or orthodox Christianity. How this plays out in the novel, however, is as important to the foundation of those relationships as it is to Atwood's comment on the value of historical "fact."

This action is not, however, without a specific plan in mind. Juxtaposing Simon's exploration of the unconscious with Grace's similar quest for self-knowledge - or more specifically, locating the former's psychological objectives within Gnostic myth - Atwood subverts the disciplinary authority of conventional psychiatric diagnoses by emphasizing the importance of Grace's spiritual needs over assumed or projected notions of physical and mental well-being. Driven to believe that hers is an affliction of the unconscious mind something in need of being remedied - Simon fails to recognize Alias Grace's penchant for alternate possibilities. Indeed, Grace's initial hesitancy to speak, we find, is not so much a desire to withhold knowledge of past events as it is her carefully-guided attempt to secure a better future for herself. Failing to achieve the same degree of self-knowledge, however, finds Simon arriving at the limitations of a scientific as opposed to spiritual mind. This 
conflict is highlighted most succinctly in the following passage, in which Jeremiah - using the alias Dr. Jerome DuPont - questions the former on his conclusions about Grace Marks:

"I have not drawn any conclusions, as yet," says Simon. "In any case, I am less concerned in [Grace's] guilt or innocence, than in [...]"

"Than in the mechanisms at work," says Dr. DuPont.

"That is not quite how I would put it," says Simon.

"It is not the tune played by the musical box, but the little cogs and wheels within it, that concern you."

"And you?" says Simon, who is beginning to find Dr. DuPont more interesting.

"Ah," says DuPont. "For me, it is not even the box, with its pretty pictures on the outside. For me it is only the music. The music is played by a physical object; and yet the music is not that object. As Scripture says, "The wind bloweth where it listeth.'"

"St. John," says Mrs. Quennell. "'That which is born of the Spirit is spirit."

"'And that which is born of the flesh is flesh," says DuPont [.. .]. (Alias Grace 85)

Given Grace's retrospective extension of this comment - that "all flesh is weak" (117) - we begin to see the novel's subversion of science in place of the spiritual; observing that as science's knowledge of the mind progressed, so too did the line between knowledge and faith also shift. When considering the view offered by Simon Jordan, however, the regard for one's spiritual needs is notably absent. "The Universe was indeed a mysterious place," Simon says, reflecting upon the Reverend Verringer's sermon; "but God had blessed mant with a mind, the better to understand whatever mysteries were truly within his comprehension" (300). Yet this is precisely the sentiment that Grace's narrative cautions against. Indeed, Gnosticism would tell us that true wisdom or gnosis is derived from recognizing the limits of our human knowledge. Grace would certainly seem to know this, but does not express it vocally; for hers is a faith rooted in self-contemplation, rather than in the greatness of man. Ironically, we learn that while Simon is both empowered and 
aroused at the thought of "rescuing" Grace, it is the reversal of power achieved through Gnosticism which suggests that it is he, ironically, who cannot be saved. In doing so, Atwood seeks to bridge a unique relationship between Grace's perspective and Simon's in the way that each deals with the knowledge given to them. Through Gnosticism, Atwood can deliver Grace Marks into a more other-worldly state, for hers is secret knowledge, striving to maintain a separation between the "public" and the "private"; and in doing so, cultivating what we are led to recognize as the divine spark within. Simon's objective, we assume, is somewhat more worldly: emphasizing man's triumph of reason over what was created by God. In feminist terms, this strategy favors, above all else, the idea of affording Grace the opportunity to rescue herself, rather than depending on a patriarchal system to do it for her. While her physical freedom is achieved in the novel by supporters who petition for her release, readers familiar with this strategy recognize by this point in the novel that much of the freedom achieved is accomplished far earlier by Grace, on her own spiritual terms. Positioning Grace's world in relation to what is occurring around her, then, is a task of some effort for the author. For despite similarities, there exists also a great discrepancy between the inner and "outer" worlds.

Uniting the spiritual and the scientific in Alias Grace finds Atwood operating on different, yet surprisingly similar levels. There are, particularly with the novel's treatment of the individual, some obvious parallels: among them, the manner by which Atwood's use of psychology suggests a penchant for Jung's discussions of the unconscious. From the standpoint of narrative strategy, this seems a logical inclusion, as it is well documented that Carl Jung was strongly influenced by explorations in Gnostic literature, and moreover, that 
his works sought to find spiritual explanations for phenomena which Freud's theories ignored. Secondly, it is worthy of note that Northrop Frye discusses Gnosticism to a certain extent (The Great Code 112), as does Robertson Davies, an explicit Jungian, in Fifth Business or The Deptford Trilogy; and together this awareness allows for a spiritual counterpoint to Simon's positioning of medical, scientific opinion.

So, it was present in literature and social ideology, but there were other attractions as well: In June Singer's Seeing Through the Visible World, she explains that psychologically - at least for Jung - an understanding of the self through Gnosticism

[...] led him to see the individual as divided in two. One part is associated with the visible world and functions through day-to-day activities by means of a practical consciousness that mediates thoughts and feelings as environmental conditions [. . .]. The other part is the Self, that aspect [...] [which] yearns toward the timeless dimension of the universe that can transcend the everyday concerns and view life 'under the aspect of eternity' [...]. [As such, we find] [. . .] fundamental gnostic questions Who am I? Where did I come from? For what purpose am I here? What is my destiny? are basically about Self-knowledge, the sine qua non for understanding the outer world and for affirming the connection with the unknown God [...]. (Singer 147)

Certainly, given past novels such as The Edible Woman or Surfacing, this idea of Gnostic dualism must have appealed to Atwood. Here, as in the novel's designs for Grace Marks, the questions of Gnostic destiny as told in relation to an individual consciousness reflect what Jung identified as an inherent similarity between the two endeavors. Indeed, Singer explains this further, noting that

Clearly it was no mere happenstance that Jung studied Gnosticism with great interest and care, and that gnostic myths and symbols informed his thinking about the greater Self - the archetype of wholeness that underlies ego-consciousness. The Self, as Jung understood it, is comparable to the gnostic concept of the alien and unknown God [...].

What the Gnostics sought was an understanding of their place in the visible world and their role in bringing to consciousness the invisible world. They realized, 
to their eternal credit, that the invisible world existed within themselves, and that therefore within themselves lay the promise and the potential for wholeness. One way in which they lived this out was in their recognition that the feminine principle and the masculine principle - in visible world terms, men and women - were equal before God and equally necessary to achieve the balanced state of wholeness that they sought to attain. Women, therefore, from the beginning of the gnostic consciousness, held an equal role with men in every aspect of their spiritual life. (Singer 98-9)

The Gnostic's desire to uncover knowledge about himself or herself is really akin to what modern psychology attempts to do, albeit accomplished in the former on a more mythic level. Utilizing that mythology in Alias Grace is perhaps the novel's greatest subtlety. Under Gnosticism, Atwood's Grace can achieve a universal station higher than that of her accusers - identifying with the greater, unknown God who is beyond the Christian God (Demiurge) - while also subverting the curiosity of Victorian society by codifying that narrative. Before such a strategy can be enabled, however, the relationship between Grace and Simon must overcome the gulf between spiritual myth and psychology. June Singer describes this in terms of the masculine and feminine principles, explaining that both are necessary to achieve a state of wholeness. Indeed, this much would seem to be true in the novel as well. Simon Jordan must be initiated into Grace's world, for his ability - or his inability - to recognize that myth is ultimately, as I shall explain shortly, the means by which Grace's true (spiritual) fate is decided in the novel.

Unfortunately for Simon Jordan, the road to gnosis - we are led to understand - is difficult, for the simple reason that its initiation is difficult. Often, Simon's first experiences with Gnosticism arrive in the form of dreams, where he imagines, in typical Gnostic fashion, a plunge into the depths of the unconscious; communicated in Alias Grace through the use of traditional Gnostic symbols. Initially, these dreams are highly eroticized. They are, as 
Jung would say, "the voice of the Unknown, that ever threatens with new schemes, new dangers, sacrifices, warfare, and other troublesome things" (Jung, Psychology and Religion 21). And this is not surprising - for truth, as it is understood in Gnosticism, emerges from the depths of unconsciousness, but appears "clothed in symbols," primarily because language is a human construct; and truth - according to many Gnostics - cannot be known in any other way. The same would appear true for Simon as well. Immediately upon hearing of the departure of Grace's father in her story, he sleeps, imagining that

The door at the end opens. Inside it is the sea. Before he can stop himself, down he goes, the water closing over his head, a stream of silvery bubbles rising from him. In his ears he hears a ringing, a faint and shivery laughter; then many hands caress him. It's the maids; only they can swim. But now they are swimming away from him, abandoning him. He calls out to them, Help me, but they are gone.

He's clinging onto something: a broken chair. The waves are rising and falling. Despite the turbulence there is no wind, and the air is piercingly clear. Past him, just out of reach, various objects are floating: a silver tray; a pair of candlesticks; a mirror [...] a gold watch [...]. Things that were his father's once, but sold after his death. They're rising up from the depths like bubbles [. . .]. He watches in horror, because now they're gathering, twining together, re-forming. Tentacles are growing. A dead hand. His father, in the sinuous process of coming back to life. He has an overwhelming sense of having transgressed.

He wakes, his heart is pounding; the sheets and comforter are tangled around him, the pillows are on the floor. He's soaked with sweat. After he's lain quietly for a time, reflecting, he thinks he understands the train of association that must have led to such a dream. It was Grace's story, with its Atlantic crossing, its burial at sea, its catalogue of household objects; and the overbearing father, of course. (Alias Grace 140).

Here we find several things. Of primary consideration is Atwood's use of the sea or turbid water; a standard symbol in Gnosticism for one's descent into matter or chaos. Beyond this, however, Simon's presence in these depths is also important. Such a descent, as it is known among the Gnostics, holds its origins accountable to many divergent speculations. Of one in particular - suggested by Simon's feelings of bondage or seduction in the novel, I look to 
Manichaeism, where, as Hans Jonas explains, the images are usually violent; but, as for the descent itself, "[ . . ] the whole process is initiated by the powers of darkness, [although] there is a voluntary element [...] with various motivations such as curiosity, vanity, [and] sensual desire [. . .]" (Jonas 63). Given that Rachel Humphrey, his impromptu lover, appears "[ . . ] dressed in black [ . . ] her veil [blowing] out behind her like dark smoke," one could assign the responsibility for that descent to her; and yet, with his actions, Atwood makes it clear that Simon too "[. . . ] says no when he means yes. He means more, he means further, he means deeper" (Alias Grace 365).

This idea of reaching down, or plunging under, is central to our understanding of Atwood's fictive psychologist. "How far, exactly, will he go?" Simon asks himself. "How far in?" (366). Initially, his surname suggests that he has the potential to cross Jordan, yet his willful exploration of the lower world would suggest, ultimately, that these aspects of his character are as much a part of his failure to cross Jordan in the novel as is any other force. While this "plunging under" is read by Simon in Alias Grace as the activity of his unconscious mind, those familiar with Atwood's pattern by this point understand it as his descent into the Gnostic depths of chaos - giving in to his sensual nature. In terms of the greater Gnostic structure, the initial cause for this is cosmic in origin. Indeed, those such as Stefan Rossbach and Hans Jonas have noted that for several Gnostic systems, "[. . . the cosmos is the world of death,"

the world is not simply a negation of life, it is actively evil, a positive force, an enemy of divinity; but if humans are more powerful than the creator of the cosmos, than their acceptance of the terms and conditions of cosmic existence requires their ignorance. The world itself is a force of darkness which is actively trying to prevent humans from obtaining knowledge of their divine nature. [...] Especially with their main weapon of love, eros, the cosmic powers know how to lead humans into their 
earthly involvement, which is possible only because of their numbness, ignorance, unawareness, sleep and drunkenness [...]. (Rossbach 53)

Simon himself would seem to know both sides: he envisions cities where "he would be anonymous, and [...] [where] he would be able to lose himself completely" (Alias Grace 366); and yet also recognizes that "[o]nce he's with Grace, things are a little better, as he can still delude himself by flourishing his own sense of purpose" (291). Such moments of enlightenment give the reader an indication of Simon's true potential. Contemplating the reasons for women's fascination in him, Atwood writes that "[a]fter a time he thought he knew. It was knowledge they craved; yet they could not admit to craving it, because it was forbidden knowledge - knowledge with a lurid glare to it. He has been where they could never go, seen what they could never see; he has opened up women's bodies, and peered inside" (Alias Grace 82). Amusingly, Atwood does not allow Simon to form a complete connection between this thought and his relationship to Grace, or to his own sense of gnosis. Instead, the deeper he goes into the sensual side of his nature, the more prominently we find it manifested, both in the dream world and in the waking world. This is shown most clearly in the novel when

He goes to bed, and sleeps at once. Then he's dreaming; an uneasy dream. He's in a fenced yard where laundry flaps on a line. No one else is there, which gives him a sensation of clandestine pleasure. The sheets and linens move in the wind, as if worn by invisible swelling hips; as if alive. As he watches - he must be a boy, he's short enough to be looking upwards - a scarf or a veil of white muslin is blown from the line and undulates gracefully through the air like a long bandage unrolling, or like paint in water. He runs to catch it, out of the yard, down the road - he's in the country, then - and into a field. An orchard. The cloth has entangled in the branches of a small tree covered with green apples. He tugs it down and it falls across his face; and then he understands that it isn't cloth at all but hair, the long fragrant hair of an unseen woman, which is twining around his neck. He struggles; he is being closely embraced; he can scarcely breathe. The sensation is painful and almost unbearably erotic, and he wakes with a jolt. (Alias Grace 195) 
Simon's distraction from the close proximity of apples in his dream by the more tempting prospect of hair affirms a juxtaposition between sexuality and knowledge as instruments of temptation; and in his case, the triumph of one over the other. Later, when he is awake, Simon comments of feminine sexuality that "he's tempted to succumb. He would choose one of their proffered young ladies, the richest one"; and that in doing so,

His daily life would be orderly, his breakfasts would be edible, his children would be respectful. The act of procreation would be undergone, unseen, prudently veiled in white cotton - she, dutiful but properly averse, he within his rights - but need never be mentioned. His home would have all the modern comforts, and he himself would be sheltered in velvet. There are worse fates. (89)

Yet, this is the very thing that Gnosticism advocates against, particularly because it is an obstacle to achieving gnosis. Atwood cannot resist the sexual pun here either, as Simon's fate indeed unfolds as something worse: notably, the aforementioned degraded relationship with his landlady, Rachel Humphrey. Though his dreams, the figure of Grace is forcing him to reflect on something - an awareness of something that is present, yet unable to approach beyond the peripheral consciousness. Readers might view it as placing the role of women central here. Jung, however, might more appropriately identify it as the female aspect of the male psyche presenting itself (Humphries 21).

Through Simon's battle between ignorance (his sensual nature) and gnosis (the spark he begins to identify with Grace), Atwood suggests the Gnostic potential within each of us to cultivate our divine origins: a potential that is only realized by engaging in that solitary process of self-awareness. Traditionally in Gnosticism, this is accomplished by engaging solely with immediate experience and observation, and not by relying upon earthly illusions of truth or fulfiliment such as family life or sexual relationships. Elaine Pagels explains this 
further, noting that

in each human being is a dwelling place, 'and that in him dwells an infinite power [...] the root of the universe.' But since that infinite power exists in two modes, one actual, the other potential, so this infinite power 'exists in a latent condition in everyone,' but 'potentially, not actually' (Pagels, The Gnostic Gospels 134-5).

I emphasize here "potentially, not actually," only because this is so important to what occurs in the novel. While unconsciously, Simon recognizes the connection he is drawing to Grace - and later reads those experiences through a framework of psychoanalytic theory - his conscious mind is less open to those ideas. The reason for this is perhaps explained by the perspective to which he has grown accustomed.

Exploring the difficulty Simon Jordan has recognizing Grace's adopted ideology, it is useful to refer once again to Elaine Pagels's discussions of the subject; that

this religious perspective differentiates gnosticism not only from orthodoxy, but also, for all the similarities, from psychotherapy, for most members of the psychotherapeutic profession follow Freud in refusing to attribute real existence to the figments of imagination. They do not regard their attempt to discover what is within the psyche as equivalent to discovering the secrets of the universe. But many gnostics, like many artists, search for interior self-knowledge as the key to understanding universal truths - "who we are, where we came from, where we go." According to the Book of Thomas the Contender, "whoever has not known himself has known nothing, but he who has known himself at the same time already achieved [his] knowledge about the depth of all things." (134)

In this we find the distance that lies between Simon and Grace: Simon's search for answers takes place on a relatively limited scale, whereas Atwood's Grace concerns herself primarily with more introspective questions. Additionally, R.D. Laing would tell us that Grace's concerns mirror distinctions often made between the embodied and unembodied self; and that indeed, one might go further to illustrate that the opinions of Grace's inner, embodied self, and its contempt for the exterior body, is in many ways akin to the Gnostics' own 
dislike for corporeal or carnal forms (71). Granted, much of the above is, arguably, in apparent contradiction to Atwood's initial methodology of drawing only from what is explicitly suggested by its time; and in particular, events in the novel seem to predate Freud's contributions by way of psychoanalytic theory. Why, then, would she include it here? To answer this, she reminds us that "[...] we tend to think of Freud as a great innovator, but the truth is that he himself rested [...] on a huge body of theoretical knowledge which had accumulated before his time. Even the famous Unconscious had made its appearance at least seven decades earlier" (Atwood, "Ophelia Has a Lot to Answer For"). Moreover, because the Simon Jordan we find in the novel "[ . . . has studied in London and Paris [. . .] [with] access to the most advanced thinking of his time," it is assumed that the most modern aspects of psychology would be available to him.

Among Simon's first considerations of Grace's character, as noted in the epigraph to this chapter, is the possibility that she is mad. Atwood is working on two levels here: the desire to diagnose Grace, suggested by both her real and invented characters' eagerness to do just that, is, she suggests, just as prominent today as it was at the time of the murders. It is also a valid approach; one Atwood both seems to expect and encourage. Terms such as "multiple personalities," "amnesia," or "sociopath" were each, in some form, inherent to midnineteenth century advances in psychology; and, implicitly, stand in direct relation to the character we discover. And yet Atwood carries another awareness here too: a second play on "madness" whose roots may be found in the novel's recognition that

when mad, at least in literature, you aren't yourself; you take on another self, a self that is either not you at all, or a truer more elemental one than the person you're used to seeing in the mirror. You're in danger of becoming, [as] in Shakespeare's works, a [. . . ] beast, and in Susanna Moodie's words, a mere machine; or else you may 
become an inspired prophet, a truth-sayer, a shaman, one who oversteps the boundaries of the ordinarily visible or audible, and also, and especially, the ordinarily sayable. (Atwood, "Ophelia Has a Lot to Answer For")

It is here that the relationship between Simon and Grace transgresses into Gnostic territory. Free to explore how her version of Grace might be saved, Atwood takes her character outside the visible world and beyond conventional boundaries of medicine or thought. Ironically, the psychologist sent to chronicle the truth about the murders is also the one who is given this spiritual knowledge; yet, in his attempt to reason through the "malady" itself, he misreads the evidence before him because the tools given to him are inadequate.

So what is Atwood trying to accomplish between them, then? In part, it seems she is relying heavily upon Gnostic myths such as that of Simon and Helen - and Simonian doctrine - as a structure for that relationship. Given the circumstances of Grace's imprisonment, and the harsh treatment she has come to know there, the reasoning for this is clear:"[t]he earliest Gnostic systems were to some extent systems of reassurance," R.M. Grant tells us; adding: "Patterned after Christianity, Simonianism recognized the presence of God in Simon and in the Simonian. Salvation was achieved by disregarding conventional morality and by setting one's hope on him and the mother-figure Helen" (Gnosticism \& Early Christianity 97). Reading this, one would assume Atwood is thinking in terms of Grace's ability to survive her more immediate concerns; and that a potential union of sorts between herself and Simon Jordan would be the source of her salvation. Atwood hints at this as well: "It comes to him [Simon] that Grace Marks is the only woman he's ever met that he would wish to marry" (Alias Grace 388), she writes, but before such a relationship is physically actualized, Simon buries the idea. Still, it would appear that he is intended here 
to fulfill the role of Simon Magus, as he is represented in Gnostic thought. There, he is a magician; a miracle worker or Father over all; a savior or Logos idea, with Helen serving as his First Thought. This is certainly in keeping with what Atwood presents as the pair's relationship in Alias Grace, and moreover, G.R.S. Mead explains that "Helen was the human soul fallen into matter and Simon the mind which brings about her redemption" (Mead 168). And as I have already established, this is what - psychologically - Simon Jordan sets out to do for Grace.

And yet, there are things unanswered. Is the light toward which Simon attempts to pull Grace the same light she desires? Presumably not. The fishing metaphor cited in the epigraph to this chapter would seem to suggest a psychological - and Christian - redemption alien to the one sought by Grace herself. Furthermore, Atwood's Simon is aware that "[. . .] there are his own requirements [to consider]. There is passion in Grace somewhere, he's certain of it, although it would take some hunting for. And she'd be grateful to him" (Alias Grace 388). And so, the salvation Simon has in mind for Grace seems quite different from her own. Yet, it seems reasonable that Margaret Atwood would turn to Gnosticism and the Simon and Helen myth: not only for its exploration of ignorance and chaos versus gnosis, but also, as a vehicle from which to explore the surrounding issue of Grace's imprisonment and peers. For although there is chaos in the depths - depths understood by Simon as the central nervous system - he seems to understand that in addition to the "shadowy central den where the human bones lie scattered and the monsters lurk," there lie "the angels also. Also the angels" (187): an apparent reference to the archons of Gnosticism who seek to keep mankind subdued in camal lust and ignorance. So, what is Simon's function here? To 
answer this, one must consider that "[t]he soul's main concern is to escape the terrible archons, and rather than meet them face to face she likes to slip by them unnoticed if she can" (Jonas 135). Such trickery would seem to imply that Grace's narrative is designed to impart that secret knowledge, but ultimately, to maintain an eye on what she and Jeremiah recognize as "the higher truth," Simon's assistance is essential.

As a resource, Simon Jordan, and Simon Magus, allows Atwood to mythologize history in a manner similar to Melville's Moby Dick: that is, by narrating her story in terms of Gnostic myth and symbols, Grace somehow escapes the trappings that have been defined for her as the processes of history itself; and, as I shall explain shortly, perhaps even returning to Genesis to write a more favorable one. For what is history without its use of language, or of names. Truth, Atwood suggests, arises from the ability to answer those Gnostic questions I mentioned earlier, and it is an individual truth bearing little or no resemblance to what is offered by way of canonical history and memory, for all too often as Atwood found in Moodie's writings - those accounts are by nature selective, or unreliable. As such, truth, as it is presented in the novel, arrives largely as symbol: facilitated not as interpersonal relationships, but primarily through Grace's accounts of immediate, tactile experience. To reach this point, Grace comes to depend on Simon Jordan as the one who will save her: he who will serve as the masculine to her feminine principle.

But what does Simon save us from? The Christians say that Jesus saves from sin, from the law, from principalities and powers, from death. But we Simonians say the same thing in a different way [...]. Simon gives us third-worldly salvation. And if we ask how this salvation is effected, we learn that it comes through the recognition of Simon and Helen, and through the rejection of conventional morality. The angels who made the world wanted to enslave men, just as they had enslaved Helen. They therefore gave commandments such as those found in law used by Jews and Samaritans alike. We, who have "set our hope" on Simon and Helen, are "saved by 
his grace, not by just works" (a quotation from Ephesians 2.8-9), and we are therefore free to do what we wish. (Grant 88)

Certainly here, this is what Atwood would like to achieve in the novel; to excuse Grace from the judgments of conventional morality by placing her outside that morality. And from this myth, we come to recognize a larger structure: Atwood's subversion of moral order within the Victorian world, led in Alias Grace by foregrounding in her protagonist's tale a noncanonical account of Creation, The Fall, and redemption.

The final correspondence with Simon and Grace in the novel finds that the former has completely fallen back into matter: into a torrid sexual relationship with his landlady, Rachel Humphrey. As he reaches the very edge of that state - and in his desperate retreat from it - he envisions Grace

coming towards him across a wide lawn in sunshine, all in white, carrying an armful of red flowers: they are so clear he can see the dewdrops on them. Her hair is loose, her bare feet; she's smiling. Then he sees that what she walks on is not grass but water; and as he reaches to embrace her, she melts away like mist. (413)

Here, the mythic structure Atwood sets up is fulfilled: Simon's descent has brought about Grace's ascent. Simon the Redeemer has completed his task, although it is an accomplishment achieved very differently than what he had initially imagined: performed outside traditional methodologies, on a mythological or spiritual level. Indeed, it is Simon and not Grace who has failed to cross Jordan. And the Myth-of-Going-Forth - in the terms I shall use to explain it - is finally realized in Alias Grace in terms that are beneficial to Grace only, because she alone has maintained the Gnostic discipline. 
The Gospel According to Grace 
Simon:

Grace's will is of the negative female variety - she can deny and reject much more easily than she can affirm or accept. Somewhere within herself - he's seen it, if only for a moment, that conscious, even cunning look in the comer of her eye-she knows she's concealing something from him. As she stitches away at her sewing, outwardly calm as a marble Madonna, she is all the while exerting her passive stubborn strength against him. A prison does not only lock its inmates inside, it keeps all others out. Her strongest prison is of her own construction. (Atwood, Alias Grace 362)

Grace:

While I am sitting out on the veranda in the afternoons, I sew away at the quilt I am making. Although I've made many quilts in my day, this is the first one I've ever done for myself. It is a Tree of Paradise; but I am changing the pattern a little to suit my own ideas.

I've thought a good deal about you and your apple, Sir, and the riddle you once made, the very first time that we met. I didn't understand you then, but it must have been that you were trying to teach me something, and perhaps by now I have guessed it. The way I understand things, the Bible may have been thought out by God, but it was written down by men. And like everything men write down, such as the newspapers, they got the main story right but some of the details wrong.

The pattern of this quilt is called the Tree of Paradise, and whoever named that pattern said better than she knew, as the Bible does not say Trees. It says there were two different trees, the Tree of Life and the Tree of Knowledge; but I believe there was only the one, and that the Fruit of Life and the Fruit of Good and Evil were the same. And if you ate of it you would die, but if you didn't eat of it you would die also; although if you did eat of it, you would be less bone-ignorant by the time you got around to your death.

Such an arrangement would appear to be more the way life is.

I am telling this to no one but you, as I am aware it is not the approved reading. (Atwood, Alias Grace 459) 
Earlier in this thesis, I refer to Hans Jonas's description of Gnosticism as "the emphasis on knowledge [in the Gnostic movements] as the means for the attainment of salvation, or even as the form of salvation itself [. . .]" (Jonas 32). I also acknowledge the "radical dualism" Jonas observes in Gnostic conceptions of existence - binaries separating "God and the world, spirit and matter, soul and body, light and darkness, good and evil, life and death." Having already reviewed then, the novel's penchant for recognizing connections between Gnostic belief and Jungian psychology, and elsewhere, Jeremiah's function as World-savior, rescuing "all who have the light-spark within them" (Mead 179), I apply my focus here to Grace Marks herself. Specifically, I intend to discuss how Atwood accomplishes a Gnostic revision of Alias Grace's central character and, additionally, what some of the implications of this restructuring might be (particularly with an eye for narrative strategies incorporated therein). Using Atwood's 1979 stage play "Grace" as a point of departure then, I examine the steps taken by Atwood to develop a version of Grace Marks that best secures her own feminist ideals, while also revisiting how her foray in Gnosticism mines a larger crisis of faith that unfolded during the mid-nineteenth century. Integral to this discussion is Atwood's use of Gnostic mythology to shape Grace's moral character; most visibly, through Simonian readings of salvation, but also, through reinterpretations of the Genesis creation myth found in both Orphic and Valentinian teachings. In doing so, the extent of the novel's matriarchal (or at the very least its anti-patriarchal) position is revealed, so that Margaret Atwood's construction becomes, then, an image not unlike Grace's "Tree of Paradise" design: a powerful triumvirate of outcast women, secretly united as one. Doing so not only establishes a clever feminist strategy on Atwood's part - allowing her to subvert 
a highly-gendered, hostile environment for women in Canadian history by re-imagining the circumstances more in Grace's favor - but it evokes something else as well: what I shall outline here as "The Gospel According to Grace."

As an introduction, then, I end where Grace begins. Returning to Atwood's stage play, one notices that the version of Grace Marks we find in the novel begins to reveal itself. Following the description of Grace given by Moodie in Life in the Clearings, Atwood's 1979 play initially seems to offer little by way of differentiation from its parent form; and yet, unlike Moodie's portrayal, or even that of Atwood's earlier teleplay, it is here that Grace's moral ambiguity first takes shape. In context, the following monologue appears as a quiet moment in the play: an opportunity in which Grace's future in the Kinnear household might be contemplated. By itself, however, it supports a greater uncertainty. Of greater things.

I've always tried to do what's right. I was brought up that way, though. We believed in doing what's fair and right. It's harder for the poor to do what's right [...]. But [life in the colony] isn't like I expected. Look out the window, MacDermot (sic) [. ..] there's nothing out there [...] nothing. And it goes on and on. Sometimes at night I feel like I' $m$ still shut up in the darkness of the boat, just floating and floating, and if I tried to go out of this house it would be just like the ocean, it would be nothing. I feel I'm drowning. It's the snow, we never had that at home [...] it takes the soul out of me somehow. It's blasphemous, I know, but when I look out of the window I think: there's no God out there. There's no one to see what you do. (Atwood, "Grace" 31)

Here, the Grace we find holds a far greater complexity than found elsewhere in Atwood's writing. Even Susanna Moodie, whose version relies on a sordid tale of lust and jealousy to force Grace's hand to its conclusion, seems weaker somehow. Notably, however, there are two things going on in this passage: first, Atwood is still working through the Frygian consciousness that pervaded much of Canadian literary studies during the 1970s. 
Responding both to the idea of Grace Marks as the "transplanted European," and to the fears of the landscape itself, Atwood is drawing parallels here between Grace's immigrant experience and Moodie's. Citing the many spiritual dilemmas felt by the latter during her lifetime, John Thurston notes, as Grace does, that Moodie's "crime may have been to ignore the 'mysterious warnings' of Providence [that she should not have come] [. . .]. With no figure of spiritual authority to contradict that thought, with so many examples of English gentry degraded by the bush, and with her values insulted by all she saw of the colony, there were no more guarantees of moral choice [...]" ("The Casket of Truth" 6). Moodie's view of Grace is as an immoral woman, but only if she is judged according to conventional morality. This is another discussion involving moral displacement. Citing Northrop Frye's observations of European value systems in the colony - and the patterns they exhibit in Canadian fiction, William Closson James notes that such "imports [. . . ] were bound to create in the immigrant to Canada a feeling that nature is threatening and hostile." Moreover, "indifference in the landscape," he tells us, creates "an identity driven to the last stand of total isolation [...] [and will] define itself only by extinction unless it can make some effort of rebirth" (James 64). Grace's attempts to do this much brings us to my second point: we see in this passage the emergence of a Gnostic outlook or perspective; an aspect of Grace's character later crucial to the Alias Grace's narrative strategy. For the imprisoned and already-criminalized Grace, this development would have been attractive to Margaret Atwood as, until this time, she says, those who supported the historical Grace Marks during the trial saw not an intelligent young girl, but instead, "were promoting the idea of her simple-mindedness [...] [for this] would tell more in her favor, [despite the fact that] it was 
obvious from her later history that she was not at all simple-minded" (Atwood, "Natural Bom Quilter").

It is useful, then, in this description of Grace's "evolution" to compare the earlier passage from "Grace" with another from Alias Grace, for which the parallels between them - and the new considerations forced - becomes apparent. The passage in question occurs in the novel as Grace and James McDermott make their escape in the night to the United States following the murders, during which Grace remarks:

But then I looked, a part of [the sky] began to wrinkle up, like the sun on scalding milk; but harder and more brittle, and pebbled, like a dark beach, or like black silk crepe; and then the sky was only a thin surface, like paper, and it was being singed away. And behind it was a cold blackness; and it was not Heaven or even Hell that I was looking at, but only emptiness. This was more frightening than anything I could think of, and I prayed silently to God to forgive my sins; but what if there was no God to forgive me? And then I reflected that perhaps it was the outer darkness, with the wailing and the gnashing of teeth, where God was not. And as soon as I had this thought, the sky closed over again, like water after you have thrown a stone; and was smooth again and unbroken, and filled with stars. (Alias Grace 335)

Atwood is clearly making a reference to Gnosticism here: Grace's maturing awareness of the universe as a closed system essentially repeats an image of the Gnostic cosmos, "[ . . ] deprived of its supreme divinity [ . . ] a confined space, beyond which there was another world [. . . the world of light [that] was the world of freedom" (Rossbach 53-4). As such, those such as Hans Jonas ponder " $[$. . . ] with what feeling gnostic men [and women] must have looked up to the starry sky";

How evil its brilliance must have looked to them, how alarming its vastness and the rigid immutability of its courses, how cruel its muteness! The music of the sphere was no longer heard, and the admiration for the perfect spherical form gave place to the terror of so much perfection directed at the enslavement of man. The pious wonderment with which earlier man had looked up to the higher regions of the universe became a feeling of oppression by the iron vault which keeps man exiled 
from his home beyond. [...] [And yet,] the total gnostic view is neither pessimistic nor optimistic, but eschatological: if the world is bad, there is the goodness of the outer-worldly God; if the world is a prison, there is an alternative to it; if man is a prisoner of the world, there is a salvation to it and a power that saves. It is in this eschatological tension, in the polarity of world and God, that the gnostic cosmos assumes its religious quality. (Jonas 261)

What seems important here is Atwood's parallel between what Grace views as the terror of the night sky above her, and the sphere of fixed stars often thought in Gnosticism to be "the wall that demarcated the cosmos as a prison [. . . ] the extreme opposite of everything that is divine" (Rossbach 54). Such an image sustains a reversal established earlier in the nove! between physical prisons and spiritual ones. Furthermore, combined with the novel's concluding image of her revised Trinity, Grace's identification of this structure - while brief here - extends what, until this point, has been a very localized recognition or application of Gnostic concepts. Indeed, Frye's "terror" landscape, first seen in the passage from "Grace," has been replaced at this point in the novel by a form of "terror" cosmic landscape often associated with the Gnostics' conception of the "outer darkness."

At the outset, then, it can be argued that Atwood's use of Gnostic myth in Alias Grace serves three notable purposes: first, it provides a spiritual counterpoint to what Atwood recognizes as ongoing discussions of The Unconscious in mid-nineteenth century medicine; second, it promotes a secret doctrine, allowing Grace to subvert others' conclusions about her character; and third, it attempts to redeem the feminine under the Holy Trinity - presumably to secure Atwood's Grace a return of sorts to her divine origins. Of this last subject in particular, June Singer informs us that traditional forms of Christianity are 
decidedly guarded. Normally, she states, "the Trinity consists of a Father, Son, and Holy Spirit[...]

Notable for its absence is a fourth element, which could be matter, the feminine principle, or the demonic element. Gnosticism takes all four into account. It restores matters to a vitally important place in the visible world; redeems the feminine principle, in the image of Sophia; and recognizes the presence of the demonic, in the form of the archons [. . ] [which] represent the non-creative powers in this world, who must be recognized for what they are and confronted directly [...]. Christianity [also] regards as a high virtue the Imitatio Dei, the imitation of God, with the words, "Be ye perfect." Not so in Gnosticism, where what is sought is not perfection, but wholeness [...]. [found through] the mystical marriage between the Christ or Logos figure and the Sophia or Eros figure. [. . .][F]or the Gnostic [this] union is to be realized [in part] [,..] in the individual person. This involves the recognition of the dark side within oneself and in the world, and a willingness to face up to it [...]. [Moreover,] to approach wholeness, the gnostic ritual seeks the "bringing together of the fragments" [.. .]. (Seeing Through the Visible World 101-2)

Here, we find in Singer's words what Atwood herself has hinted at all along: that constructing one's self is very much like writing back to the self of another, or writing historical fiction for that matter - it is the bringing together of many fragments. Moreover, the Gnostics' "recognition of the dark side within oneself" is also suggestive of Jung's "shadow," or moral problem. "To become conscious of it," he writes, "involves recognizing the dark aspects of the personality as present and real. This act is the essential condition for any kind of self-knowledge, and it therefore, as a rule, meets with considerable resistance" (Stein 95).

And so, returning to Atwood's comment in "Natural Born Quilter" that "the fullness of Grace is the point," what the author really seems to allude to here is a more specific understanding of wholeness belonging to the Gnostics. For "the Fullness of the Gnostics," 
we are told, "is without qualities in and of itself, yet it contains the potentials for all that is, has been, and will be" (93). Taken more liberally, we find that

[b]efore the cosmos, there was a divine sphere of uniformity and light, called the pleroma, the 'fullness' of God. The divine world is understood as an extension and actualisation of the nature of God. Its powers are called aeons and represent the various levels of being in the divine world. Aeonic speculation is a hallmark of 'Gnostic' systems. Although there is some variation with regard to the number, gender, names and ranks of the aeons, it is usually the female sophia, Wisdom, who is the last and least of them. She is often the one who disturbs the calmness of the pleroma and becomes the cause of the great cosmic tragedy.

Human beings are created as part of the cosmos; they are created by the same demiurge who created the world. However, as part of a divine scheme to restore the original pre-cosmic state of perfection, they were given a divine spark, a flash of the divine light or substance, the pneuma, which renders them superior to their creator. Although their temporary 'home' is the cosmos, they belong to the divine world, the pleroma. (Rossbach 50-1)

Restoring the feminine element and the divine spark here allows Atwood an opportunity in Alias Grace to reclaim this "fullness," then; to subvert the patriarchal systems that have condemned Grace from within, by offering the chance at redemption that the earthly world has denied her. This would seem to make sense, and Atwood herself certainly seems to be aware of the benefits this ideology allows her. R.M. Grant explains that "the first and most important point in defining Gnosticism [is that] it is a religion of saving knowledge, recognition of the divine element which constitutes the true self" (10). And yet what becomes clear here also is that the path to achieving this awareness is not an easy one. Elaine Pagels, for instance, echoes Jung's earlier statement when she writes that: "[. . .] gnostics acknowledged that pursuing gnosis engages each person in a solitary, difficult process, as one struggles against internal resistance $[\ldots]$ the desire to sleep or to be drunk - that is, to remain unconscious" (126). Grace too is aware of this, and in the novel the 
distinction between those who achieve gnosis and those who fail by choosing to reside in ignorance, is accomplished most viscerally through Atwood's juxtaposition of Grace and Simon; the latter of whom - as I've said - retains the potential for that same self-awareness, but whose sexual tryst with his landlady, Rachel Humphrey, renders him forgetful of all that Grace has told him.

Northrop Frye once wrote that "[ . . ] if anything historically true is in the Bible, it is there not because it is historically true but for different reasons. The reasons have presumably something to do with spiritual profundity or significance" (The Great Code 40). In many ways, the same could be said of Alias Grace. Atwood's (and Grace's) attempts to redeem the feminine here - to reunite the latter with her divine origin - rests largely on Grace's ability to position her story as an alternate, though not entirely dissimilar, variation of an old myth. "The Gospel According to Grace," as I have called it, is exactly that. It is a truth based on observation; and yet, it conveys a sense of belonging as well: a becoming of textual authenticity and authority previously unknown to her. The objective of that gospel, it would seem, is the freedom from judgment under conventional morality, allowing women such as Grace "release from the world itself, a world of material existence [but only if she] practice[s] a rigid asceticism so that [her] spirit will not be defiled by the material world and its pleasures." Returning, then, to to the issue of standard images featured in Grace's story, Robert A. Segal clarifies the foundation here, explaining that

Gnostics espouse a radical, irreconcilable dualism composed of immateriality, seen as divine and wholly good, and of matter, considered wholly evil. [Most notable here:] the predicament is that pieces or sparks of immateriality have fallen into matter: human souls are trapped in bodies [. . .]. Because the spark is not merely trapped, but hidden, liberation requires the revelation of one's divinity. Salvation for 
the individual means the extrication of the spark from the body and the return to its immaterial home. Salvation for the cosmos means the retum of all sparks. The aim is to terminate any connection between immateriality and matter.

For Grace Marks, this understanding of her origins, brought to her as divine revelation by the already-discussed Jeremiah the Peddler, constitutes the former's awareness of self and place. So, how exactly does Grace achieve the creation of her gospel? As stated above, among the primary characteristics of the Gnostics include the belief in knowledge to be his or her saving grace, so to speak. Grace's tale is a highly-stylized, and codified, transmission of that knowledge. From the onset of her journey at the novel's beginning, we are led along this path of discovery; the road of which is filled with Atwood's appropriation of Gnostic influences. One of the first examples of this arrives shortly after the death of her mother. Plagued by the guilt that her mother's spirit is somehow "trapped in the bottom of the ship because [they] could not open a window [. . . ]," Grace imagines "[ that S] he would be caught in there forever and ever, down below in the hold like a moth in a bottle [and] sailing back and forth across the hideous dark ocean" (122); but also, that "there was something dreadful about it, to picture her floating down in a white sheet among all the staring fish. It was worse than being put into the earth, because if a person is in the earth, at least you know where they are"(121). Emphasizing this scene's place within the Gnostic perspective, Hans Jonas offers us an insightful way of reading this scene. "The sea or waters," he tells us, "is a standing Gnostic symbol for the world of matter or of darkness into which the divine has sunk" (Jonas 117). By fearing for the captivity of her mother's spirit in the bowels of the ship, then, Grace is actually concemed that the former is being prevented from rejoining the divine above. This "turbid water", he continues, is "water of the Abyss [or Chaos] [. . . ] the original matter 
of the world of darkness with which the living water mingled" (99). For Grace, the event provides a moment of recognition, for "[a] sea voyage and a prison may be God's reminder to us that we are all flesh, and that all flesh is grass, and all flesh is weak. Or so I choose to believe" (Alias Grace 117).

When Mary prophecizes Grace's future in the apple peelings - particularly, that the latter would pass over water three times during her life (a prediction later fulfilled in the novel) - and for this, it is likely that Atwood is referring here to what Gnostics refer to as "The Myth of the Going-forth." The tale is one that

was common to a number of schools, but Hippolytus ascribes it to an otherwise unknown school called the Peratae, supposed to mean Transcendentalists, or those who by means of the Gnosis had "passed beyond" or "crossed over." Thus then they explained the Exodus-myth. Egypt is the body; all those who identify themselves with the body are the ignorant, the Egyptians. To "come forth" out of Egypt is to leave the body; and to pass through the Red Sea is to cross over the ocean of generation, the animal and sensual nature, which is hidden within the blood [...] [and eventually, they] enter the Promised Land, the realm of the spiritual mind [...]. (Mead 185-6)

By leaving behind ignorance, and the animal side of one's nature, it is assumed that Grace enters the Promised Land by the conclusion of the novel. And yet, Atwood does not offer a resolution that is clean. Of her new home near Ithaca, New York at the novel's end, Grace informs readers that "[t]his is like Heaven. Although Heaven was not a place I ever used to think of myself as going" (Alias Grace 453), and indeed, we too are uncertain as to whether she is truly saved or not. Notably, we find that her fate, as she comes to understand it, may be either a blessing or a curse: she feels as though she might be pregnant, but "it might as easily be a tumour," she tells us, "for although there is a heaviness, I've had no sickness in the mornings" (459). Before exploring the significance of this further, however, it is useful 
to understand how Grace is able to arrive there, and the steps that must be taken to keep her newfound faith a secret. Specifically, we find that Grace's relationship to gnosis, or saving knowledge, forms the basis for both her own perspective and for the relationships she develops with the invented characters around her: most notably, her admiration for the divine spark as revealed to her by Jeremiah, and her contempt for those around her who dwell in a state of ignorance.

As Hans Jonas states in The Gnostic Religion, "[f]or more than one reason, not the least of which was the mention of 'knowledge,' [this] biblical tale exerted a strong attraction upon the Gnostics" (93). Rather than the traditional Christian view of the serpent, a tempter who led Eve and Adam to first eat of the Tree of Knowledge and defy God, it was the serpent who, for many Gnostics, was responsible for giving man knowledge of his divine origins. Certainly, a regard for the serpent is present in Alias Grace. In the final chapter, entitled "The Tree of Paradise," Grace is found to be making a quilt for herself, and when deciding the form it will take, she explains that "I intend to put a border of snakes entwined; they will look like vines or just a cable pattern to others, as I will make the eyes very small, but they will be snakes to me; as without a snake or two, the main part of the story would be missing" (459-60). The story, of course, is the story of Genesis; only, it is a Gnostic re-telling of Genesis. The significance of this is revealed in part when one considers that only in Gnosticism is there one united concept of good and evil; and, moreover, it is only this system of thought which affirms the importance of the serpent-tempter as the provider of knowledge..$^{24}$ 
When Simon Jordan asks Grace about the apple he offers to her, Atwood is very cautious about the handling of this scene; for although Grace would indeed be tempted by such an item, its significance here lies in the allusion Atwood is making to a forbidden object: a hidden knowledge - of which Grace remarks that:

I am so thirsty the apple looks to me like a big round drop of water, cool and red. I could drink it down in one gulp. I hesitate, but then I think, There's nothing bad in an apple, and so I take it. I haven't had an apple of my own in a long time [. . . I. I stand holding the apple in both hands. It feels precious, like a heavy treasure. I lift it up and smell it. It has such an odour of outdoors on it I want to cry [...]. The truth is I don't want him watching me while I eat. I don't want him to see my hunger. If you have a need and they find it out, they will use it against you. (39-40)

Later, after asked by Simon if there is a kind of apple one should not eat, Grace is quick to "give [her] stupid look," before acknowledging to the reader: "The apple of the Tree of Knowledge, is what he means. Good and evil. Any child could guess it. But I will not oblige [. . .]. I look at him. I look away. I look at him again. I hold the apple in my two hands. He waits. Finally, I lift the apple up and press it to my forehead" $(40,42)$. The temptation in this scene - and more importantly, Grace's desire not to show her temptation - proves crucial to our understanding of her position. Hers is a religion of salvation, yet to reveal the knowledge she possesses would be to risk that salvation. Indeed, it is not until she is safely across the waters at the end of the novel, leaving behind what Mary and Jeremiah have taught her is a world of ignorance and distrust, that we first begin to see her relax her vigilance against those who once posed a threat of further persecution.

Atwood, here, is reflecting a more historical truth: an erasure of knowledge which led to the necessity of self-preservation among the Gnostics; particularly with respect to the continued teachings of that knowledge. Retrospectively, June Singer tells us that 
[...] all that we knew about Gnosticism was what we had learned from texts - most of them Christian - denouncing these sects as heretical. Since gnostic writings often took positions at variance with the developing Christian tradition, as well as the earlier Judaic tradition, they were treated as gross heresies.

[Consequently] [. . .] rather than risk having their books burned or, still worse, having their authors burned, the Gnostics learned to keep themselves out of view, and their books remained for the most part secret doctrines, imparted only to those who had been initiated into this special company. (87)

Here, we find that the need for secrecy was vital to the continuation of the gnostic tradition; and dually, that "[s]ecrecy becomes the key to the superiority of these Gnostics over the archons as well as over the ignorant part of mankind - for only they possessed the secret knowledge necessary in order to not miss salvation"(58). For those like Grace and Jeremiah, knowledge is imparted only to those identified as belonging to the spiritual elite, for they alone hold a matured understanding of their place within the cosmos, and the tools by which they might complete the Gnostics' conception of "wholeness."

What I haven't discussed to this point, however - and therefore, what I have chosen to end my discussion with here - is Atwood's treatment of the murders themselves in Alias Grace. While I maintain my original contention that the novel's approach to the murder is less consequential than the events or machinations transpiring around it, it does seem necessary to address its place within the novel's greater structure. Certainly, the author does not allow for easy conclusions to be drawn. She does, however, hint at possibilities which -despite their inconclusive nature-ultimately serve the novel's refusal to make a judgment. If Grace did not participate in the murders, then everything I have discussed holds true: like "Susannah and the Elders," Grace has been falsely accused by her male peers for betraying a socially-constructed ideal. Yet, if she did take part in the crimes, Atwood offers her an 
escape here also. Such actions, she suggests, would belong to a woman of an unsound mind: something hinted at - but never fully answered - in Jerome DuPont's seance, and by the internal "Mary Whitney" and "Nancy Montgomery" personalities of whom Grace seems to be aware. What seems more likely, however, is that the murder does fit within the Gnostic structure I've identified within the novel. Just as Gnosticism promotes one's self-acceptance of both the good and evil side of one's nature as one of the final acts toward achieving gnosis, so too might the Kinnear-Montgomery murders in the novel be read as crimes of necessity; perpetrated, paradoxically, to allow Grace to achieve a form of final, ultimate knowledge of that which resides within her: her awareness, for instance, of a hand that "was not mine at all, but only a husk or skin, with inside it another hand growing" (Alias Grace 317).

"You see what queer ideas a person can get," Grace tells us, adding: "but I was only a young girl at the time, and very ignorant" (Alias Grace 122). Indeed, this would seem an apt statement for much of the novel: the distinction between "pre-" and "post" states as they relate to knowledge, history, the Fall, imprisonment, and similarly, redemption. One of Grace's final conclusions - told after the murders - finds her asking:

[. . . ] why did I need to pray, when God was right there, hovering above us like the Angel of Death over the Egyptians, I could feel his cold breath, I could hear the beating of his dark wings, inside my heart. God is everywhere, I thought, so God is in the kitchen, and God is in Nancy, and God is in McDermott, and in McDermott's hands, and God is in the axe too. Then I heard a dull sound from within, like a heavy door closing shut [...]. (317).

The door, Atwood suggests, is the door of memory: now an inability (or an unwillingness) to return to a previous state of knowledge or ignorance; a state paralleled medically, we read, 
by the possibility of a psychological break from what came before. As readers, the allusion is clear. "Here we are," Atwood tells us, "right back at the twentieth century, with our own uneasiness about the trustworthiness of memory, the reliability of story, and the continuity of time" ("In Search of Alias Grace" 1515). And as before, the question remains the same: "Where do we go from here?" 
Conclusion (Thrice-Crossed Waters) 
When you are in the middle of a story it isn't a story at all, but only a confusion; a dark roaring, a blindness, a wreckage of shattered glass and splintered wood; like a house in a whirlwind, or else a boat crushed by the icebergs or swept over the rapids, and all aboard powerless to stop it. It's only afterwards that it becomes anything like a story at all. When you are telling it, to yourself or someone else. (Alias Grace 298) 
To answer this question: "Where do we go from here?", I return to the issues which originally informed my discussion. Several times throughout this essay Ihave cited Margaret Atwood's "In Search of Alias Grace" for the insight it provides into the evolution and direction of historical novels in Canada. We find in the author's approach to Grace Marks a clever and subversive means for underscoring women's histories through the use of a specifically non-canonical framework, reminding us that " $[\ldots]$ the authors of [historical narratives] are individuals" (1510), and that "[...] each novel has its own preoccupations." Gnosticism provides a timely and suitable vehicle for this; and indeed, Atwood seems to be attracted to those literatures; presumably because narratives such as Grace's, "insofar as it is private and self-directed, [are] the instrument of a self-contemplation [and] [. . .] necessarily 'gnostic"' (Humphries 7). Ultimately, it communicates little to the good of the community, or to a greater cause, but rather, focuses solely on the needs of the individual. For this reason, Gnosticism has traditionally been viewed as a "selfish" religion - both in content and in principle - even though authors such as Atwood do not appropriate it for explicitly selfish acts. Instead, women such as Grace Marks, she suggests, are drawn to Gnosticism because it applies meaning to everyday history: it makes its home in the individual.

Taking us back to the beginning - to the original Creation myth - seems inevitable, and perhaps even essential, to the use of that structure, then. William Blake once wrote that "[b]oth read the Bible, day and night; but you read black where I read white" (Hoeller); and indeed, one might say that Atwood's Grace embodies this sentiment. Her approach to the Bible is that of a critic; a person familiar with patriarchal agendas and the tools of narrative 
construction. The distinction made between her reading of Genesis and that of the more orthodox community is an important one, because it helps to explain some crucial questions. Indeed, Grace's view of the serpent in relation to knowledge is vastly different from the other characters in the novel: through the Gnostic perspective, her place within that myth is as a participant in a divine drama: a series of narrative acts chronicling the Fall and redemption of man, fulfilled when she joins the Unknown God beyond the outer darkness. Reading it as such, the patriarchal forces which seek to define and contain her as a this-worldly "history" lose importance. Indeed, Stephan A. Hoeller tells us that

[t]he orthodox view [. . . ] regarded most of the Bible, particularly Genesis as history with a moral. Adam and Eve were considered to be historical figures, the literal ancestors of our species. From the story of their transgression, orthodox teachers deduced specific moral consequences, chiefly the 'fall' of the human race due to original sin. Another consequence was the lowly and moral ambivalent status of women, who were regarded as Eve's co-conspirators in the fateful deed of disobedience in paradise.

[. . . The Gnostic Christians who authored the Nag Hammadi scriptures did not read history with a moral, but as myth with meaning. To them, Adam and Eve were not historical figures, but representatives of two intrapsychic principles within every human being. Adam was the dramatic embodiment of psyche, or soul, while Eve stood for the pneuma, or spirit. Soul, to the Gnostics, meant the embodiment of the emotional and thinking functions of the personality, while spirit represented the human capacity for spiritual consciousness. The former was the lesser self (the ego of depth psychology), the latter the transcendental function, or the 'higher self,' as it is sometimes known. Obviously, Eve, then, is by nature superior to Adam, rather than his inferior, as implied by orthodoxy.

As I have discussed, Atwood's explorations of the above in relation to Biblical construction become an apt metaphor in the novel - and in life - for the often difficult assemblies of "canonical" history. For someone such as Grace Marks, who is both condemned and/or excluded from those assemblages - physically, spiritually, and textually - Gnosticism 
becomes a very attractive ideology.

As a language through which to work, Grace's is symbolically-charged and laden with hidden meaning, effectively blurring the boundary between "historical narrative" and "gospel." The effect is such that the reader is reminded of Atwood's play here with notions of textual authority, and of the utterance in speech. "In the courtroom, every word that came out of my mouth was as if burnt into the paper they were writing it on," Grace tells us (Alias Grace 68-9);

and once I said a thing I knew I could never get the words back; only they were the wrong words, because whatever I said would be twisted around, even if it was the plain truth in the first place [. . . . But now I feel as if everything I say is right.

It is right, of course, because the language is more favorable to her circumstances. June Singer explains it by noting that

Gnostic writing is surely ahistorical: it has nothing to do with people who ever lived in this world or with events that have any historical reality. But it has a psychological validity, in that it comes from the soul or psyche of the human being, and is expressed in the language of the collective soul, or the collective unconscious as Jung would say - a language that finds its way to us through myth and metaphor. (Singer 99)

Under this system, Grace's re-telling of the events leading to the Kinnear-Montgomery murders functions not as a means of historicizing the event, but of mythologizing it: of positioning it outside traditional forms of narration. This is, we read, why Grace's tale is at times puzzling to Simon Jordan. It is because he does not have the tools to understand the dominant patterns of symbols.

This is a particularly important consideration when pondering why the author likely chose Gnosticism to frame the novel. Aside from the more obvious feminist advantages, 
historically, it seeks to re-write, or to re-create. While one aspect of Gnosticism stresses the importance of the individual, and of self-contemplation, it is at the same time necessarily involved - even if peripherally - with greater events. I am referring here to those such as Hans Jonas, who assert that

[. . . gnosis is not a mere passive devotion to mythical themes. [But rather,] [b]y knowing humanity's history, the knowing person is directly and prominently involved in the drama that is the history of humankind. The theoretical appropriation of the myth is already the practical suspension of its contents. Each act of individual enlightenment forms an immediate contribution to the restoration of divine fullness. Therefore, the myth incorporates the knower's presence, his knowing, into the myth. The narration of the myth ends with an individual becoming aware of his divine origin. Hence, it ends with the myth becoming known and then continues as the history of the knower, who is on his [or her] route towards certain salvation. (Rossbach 56)

By conflating myth and history, Margaret Atwood locates in Alias Grace a circular, selfcreating narrative of both Genesis and salvation. The narrative itself - which comprises the novel, is ironically what we may read as one of the tools by which Grace is presumably though not definitively - saved by the novel's conclusion. It is an open system, accommodating and incorporating those experiences as each new being passes the threshold of knowing, or gnosis.

To bring us back to the crime, however, Atwood wonders: "[ . . .] is it not, today well, somehow unfeminist - to depict a woman behaving badly?"

Isn't bad behavior supposed to be the monopoly of men? Isn't that what we are expected-in defiance of real life-to somehow believe now? When bad women get into literature, what are they doing there, and are they permissible, and what, if anything, do we need them for? (Atwood, "Spotty-Handed Villainesses")

But we do need them, I would argue. Like Atwood's answer to the question - that "we do need something like them [. . .] something disnuptive to static order" - it would seem thai 
women such as Grace Marks embody the best and the worst of what Canadian literature and history - have to offer: the potential for constructing or deconstructing representations of women behaving badly. To explore those histories seems necessary, even prudent; and moreover, in Canadian fiction these efforts would seem a timely venture; for "[ $t]$ he past no longer belongs to those who once lived it," Atwood tells us ("In Search of Alias Grace"). Instead, "[t]he past belongs to those who claim it, and are willing to explore it, and to infuse it with new meaning for those who are still alive today. The past belongs to us, because we are the ones who need it." 
Notes

1. Northrop Frye, The Bush Garden: Essays on the Canadian Imagination (Toronto: Anansi, 1971) 225.

2. I am thinking here of Hutcheon's discussion about the institution of literature; a space "[. . . ] of writers and readers, producers and receivers of texts, and also of the "circumstantially dense interchange' between them, an interchange that has social, historical, and ideological dimensions" (The Canadian Postmodem 73).

3. Full title: "In Search of Alias Grace: On Writing Canadian Historical Fiction." In this essay - originally delivered at the Bronfman Lecture, Otawa, in November 1996-Atwood comments on the rise of the Canadian historical novel, while sharing also her own experiences and observations of the genre as she was writing Alias Grace.

4. I should note here that Jonathan Spence does concede in his essay, "Margaret Atwood and the Edges of History," that historians too "may draw conclusions that are equivalent to filling gaps"; or later, "may juxtapose pieces of information in such a way as to embue them with new meanings." At the heart of his argument, however - and the reason for his inclusion here - is his claim that "the historian earns the right to bear a kind of witness, to speak with greater authority than others" about the past (1523-4).

5. Judith Knelman explains that in real life, Grace did not deny being a witness to Kinnear's murder, but insisted that her involvement was the result of coercion by [James] McDermott. And yet, Nancy was found with Grace's scarf drawn tightly around her neck; and James Welch, a neighbor, claimed that Grace acted suspiciously that evening when he asked where Nancy was ("Can We Believe..." 680).

6. I am indebted to Margaret Atwood for her kind permission to include both The Servant Girl ("Grace Marks") and "Grace" in my research; and to Edna Hajnal at the University of Toronto's Thomas Fisher Rare Book Library for arranging to have copies of both works sent to me.

7. Recently, Atwood has observed that "[f]or each story, there was a teller, but - as is true of all stories - there was also an audience; both were influenced by the received climates of opinions, about politics, and also about criminality and its proper treatment, about the nature of women - their weakness and seductive qualities, for instance - and about insanity [... .]." ("In Search of Alias Grace" 1515)

8. Atwood is referring here to William Harrison Ainsworth, a nineteenth-century British author of popular historical romances. The connection she draws to Moodie is likely on account of Ainsworth's appointment to Editor of Richard Benuley's Miscellany in 1839, under whom Susanna Moodie was also publishing. It is likely, then, that Moodie would have been familiar with Ainsworth's writings.

9. It is amusing, and perhaps worthy of note here that Atwood plays with Moodie's alleged name-change strategy in Alias Grace. In a scene near the novel's opening, her Grace is reading scrapbooks and finds a poem signed "Your loving 'Nancy, ' Hannah Edmonds" (Alias Grace 26).

10. I am referring here to Faith's examination of the rebel woman; "[. . . ] the defiant woman who rejects authority [. . ] the unmanageable woman who claims her own body, the whore, the wanton woman [. . . [she] who lacks the resources to wrap herself in the cloak of middle-class femininity" (1). It is interesting that Unruly Women made its appearance in 1993. Known in Criminology circles, this study of female criminality and its associated representations would have made valuable reading material for Atwood during the time of Alias Grace's conception. My thanks to Professor John Whatley for drawing my attention to this work. 
11. Karlene Faith, Unruly Women: The Politics of Confinement and Resistance (Vancouver, BC: Press Gang Publishers) 24-9.

12. George Eliot's (Marian Evans), The Mill on the Floss (Edinburgh: W. Blackwood, 1860).

13. My thanks to Professor Sandra Djwa for noticing the similarities between the public's reception of Paul Bemardo and Karla Homolka's relationship, and that of Grace Marks and James McDermott's.

14. For further reading, see: Arnold E. Davidson and Cathy N. Davidson, The Art of Margaret Alwood: Essays in Criticism (Toronto: Anansi, 1981) and Lorraine M. York, ed., Various Anwoods (Concord, Ont: House of Anansi Press, 1995).

15. Stefan Rossbach's Gnostic Wars: The Cold War in the Context of a History of Western Spirituality offers an ambitious, and very useful, deconstruction of some of the major issues inherent to Gnostic studies; and, in particular, re-evaluates Hans Jonas's seminal work The Gnosric Religion with respect to new directions of study and unanswered questions in Jonas's framework.

16. G.R.S. Mead, Fragments of a Faith Forgonen (New York: University Books, 1960) 285-97; 50, 54.

17. Full title: "'The Casket of Truth': the Social Significance of Susanna Moodie's Spiritual Dilemmas." In this article - useful to the Moodie enthusiast - John Thurston traces the various spiritual dabblings of both Moodie and her husband in relation to their respective choices of literary endeavors at varying points in their lives, and speculates as to why those leanings might have been attractive.

18. I am generalizing here somewhat, of course, for the purposes of clarity. The Apocrypha's collection of many texts contains a variety of texts which mention Mary. Though I risk homogenizing them here, I do so for the purpose of clarity, and to emphasize their roles as non-canonical texts.

19. See: Hans Jonas, The Gnostic Religion (Boston: Beacon Press, 1963) 283; and G.R.S. Mead, Fragments of a Faith Forgonen (New York: University Books, 1960) 285-7.

20. Valentinus was an influential leader in Gnostic thought during the second century. See: G.R.S. Mead, Fragments of a Faith Forgotten (New York: University Books, 1960) 285.

21. It is important to note that the Gnostics were not unanimous in affirming women. Indeed, certain Gnostic texts speak of the feminine with contempt, although typically in reference not to women themselves, but rather, the power of sexuality (Pagels 66).

22. A greater discussion of psychotherapy as it relates to religion and Gnosticism can be found in the proceeding chapter on Simon Jordan.

23. The parallel between physical and spiritual confinement is first made during Grace's voyage to Canada in the novel; repeated throughout the novel as an unsettling though of her mother's and Mary's spirits being eternally trapped; for Mary, in the room where she died; and for Grace's mother's, in the hull of the boat itself).

24. G.R.S. Mead, Fragments of a Faith Forgotten (New York, University Books, 1960) 183-8. 
Works Cited

Atwood, Margaret. Alias Grace. Toronto: McClelland \& Stewart Inc, 1996.

—. "Blood and Laundry." Interview with Laura Miller. Salon. January 1997 <http://www.salon.com/jan97/interview970120.html>.

-. The Edible Woman. Toronto: McClelland \& Stewart Inc., 1969.

—. "Grace." 1979.

-. "Grace Marks" (see also: The Servant Girl). The Play's the Thing. Canadian Broadcasting Corporation. 1974.

-. The Handmaid's Tale. Toronto: McClelland \& Stewart Inc., 1985.

-. "In Search of Alias Grace: On Writing Canadian Historical Fiction." American Historical Review 103.5 (1998): 1503-16.

-. Interview. Mail on Sunday (UK). n.d.

-. The Journals of Susanna Moodie. Toronto: Oxford University Press, 1970.

-. "Natural Born Quilter." Interview with David Wiley. Arts \& Entertainment. 23 January 1997.

-. "Ophelia Has a Lot to Answer For." The Margaret Atwood Information Web Site. Ed. RaWeB Editing and Web Design. 1997. O.W. Toad. 1 October 2000 <http://www.web.net/owtoad/ophelia.html>.

-. "Spotty-Handed Villainesses: Problems of Female Bad Behaviour in the Creation of Literature." The Margaret Atwood Information Web Site. Ed. RaWeB Editing and Web Design. 1997. O.W. Toad. I October 2000 <http://www.web.net/owtoad/ophelia.html>. -. Surfacing. Toronto: McClelland \& Stewart Inc., 1972. 
Blake, William. The Book of Urizen. [Coral Gables, Fla.]: University of Miami Press, [1966].

-. Vala; or, The Four Zoas. Ed. G.E. Bentley, Jr. Oxford: Clarenden Press, 1963.

Cantor, Paul A. Creature and Creator: Myth-making and English Romanticism. London:

Cambridge University Press, 1984.

Clayton, Mary. The Apocryphal Gospels of Mary in Anglo-Saxon England. London: Cambridge University Press, 1998.

Faith, Karlene. Unruly Women: The Politics of Confinement and Resistance. Vancouver, BC: Press Gang Publishers, 1993.

Findley, Timothy. Famous Last Words. Toronto: Clarke, Irwin, c.1981.

Frye, Northrop. The Great Code: The Bible and Literature. 1983. Toronto: Penguin Books, 1990.

"The Gospel of Mary." The Nag Hammadi Library in English. Trans. Members of the Coptic Gnostic Library Project of the Institute for Antiquity and Christianity. San Francisco: Harper \& Row, Publishers, 1977. 471-4.

Grant, R.M. Gnosticism and Early Christianity. $2^{\text {nd }}$ ed. New York: Columbia University Press, 1966.

Hoeller, Stephan A. "The Genesis Factor." The Gnosis Archive. 1928. 6 October 2000 $<h t t p: / / w w w . g n o s i s . o r g / g e n e s i s . h t m l>$.

Humphries, Jefferson. The Othermess Within: Gnostic Readings in Marcel Proust. Flannery O'Connor, and Francois Villon. Baton Rouge, LA: Louisiana State University Press, 1983. 
Hunt, Lynn. "'No Longer an Evenly-Flowing River': Time, History, and the Novel." American Historical Review 103.5 (1998): 1517-21.

Hutcheon, Linda. The Canadian Postmodern: A Study of Contemporary English-Canadian Fiction. Toronto: Oxford University Press, 1988.

James, William Closson. Locations of the Sacred: Essays on Religion, Literature, and Canadian

Culture. Waterloo, Ont.: Wilfrid Laurier University Press, 1998.

Jonas, Hans. The Gnostic Religion: The Message of the Alien God and the Beginnings of

Christianity. $2^{\text {nd }}$ Rev. ed. Boston: Beacon Press, 1963.

Jung, C.G. Psychology and Religion. 1938. Fort Village, MA: The Murray Printing Company, 1963.

Knelman, Judith. "Can We Believe What the Newspapers Tell Us? Missing Links in Alias Grace." University of Toronto Quarterly 68.2 (1999): 677-86.

- Twisting in the Wind: The Murderess and the English Press. Toronto: University of Toronto Press, 1998.

Laing, R.D. The Divided Self: An Existential Study of Sanity and Madness. London: Tavistock Publications, 1960.

LeClair, Tom. "Quilty Verdict." Rev. of Alias Grace, by Margaret Atwood. The Nation. 9 December 1996. n. pag.

Marlowe, Christopher. Doctor Faustus. Ed. Roma Gill. New York: Hill and Wang, 1966.

Mead, G.R.S. Fragments of a Faith Forgotten: A Contribution to the Study of the Origins of Christianity. New York: University Books, 1960. 
Melville, Herman. Moby Dick: or. The Whale. 1952. Ed. Luther S. Mansfield and Howard P.

Vincent. New York: Hendricks House, 1962.

Milton, John. Paradise Lost. Ed. Alastair Fowler. London; New York: Longman, 1998.

Moodie, Susanna. Roughing It in the Bush. London: R. Bentley, 1852.

一. Life in the Clearings Versus the Bush. London: R. Bentley, 1853.

Moore, Alison. "A Mesmerizing Murderess." Rev. of Alias Grace, by Margaret Atwood.

Tucson Weekly. 16 January 1997 . I October 2000

$<$ http://www.tucsonweekly.com/tw/01-16-97/review3.htm>.

Murphy, Bernice M. "Subverting from Within." Rev. of Alias Grace, by Margaret Atwood. The Imperial Archive Project. 1 October 2000

<http://www.qub.ac.uk/en/imperial/canada/alias-grace.htm>.

Nuttal, A.D. The Alternative Trinity: Gnostic Heresy in Marlowe, Milton and Blake. New York: Oxford University Press, 1998.

Pagels, Elaine. The Gnostic Gospels. New York: Random House, 1979.

Rexroth, Kenneth. Introduction. Fragments of a Faith Forgotten: A Contribution to the Study of the Origins of Christianity. By G.R.S. Mead. New York: University Books, 1960. vi-xx.

Rossbach, Stefan. Gnostic Wars: The Cold War in the Context of a History of Westem

Spirituality. Edinburgh: Edinburgh University Press, 1999.

Scott, Sir Walter. The Lady of the Lake [microform]. Ed. T.C.L. Armstrong. Toronto: Canada Pub. Co., 1881.

Shelley, Mary. Frankenstein, or, the Modem Prometheus. Ed. D.L. Macdonald and Kathleen Sherf. Peterborough, Ont.: Broadview Press, c.1999. 
Singer, June. Seeing Through the Visible World: Jung, Gnosis, and Chaos. San Francisco: Harper \& Row, Publishers, 1990.

Spence, Jonathan D. "Margaret Atwood and the Edges of History." American Historical Review 103.5 (1998): 1522-25.

Taketani, Etsuko. "Moby Dick: Gnostic Re-Writing of History." <http://www.ebscohost.com>. Fulltext rpt. of ATQ. 8.2 (1994): 119-36.

Thurston, John. "'The Casket of Truth': the Social Significance of Susanna Moodie's Spiritual Dilemmas." Eaculty of Arts Research Web Site. University of Western Ontario. <htp://arts.uwo.ca/canpoetry/cpirn/vol35/thurston.htm>.

White, Hayden. "The Value of Narrativity in the Representation of Reality." Narratology. Ed. Susana Onega and Jose Angel Garcia Landa. London: Longman Group Limited, 1996. 


\section{Works Consulted}

Bal, Mieke. Narratology: Introduction to the Theory of Narrative. 1985. $2^{\text {nd }}$ ed. Toronto: University of Toronto Press, 1997.

Davidson, Amold E. and Cathy N. Davidson, eds. The Art of Margaret Atwood: Essays in Criticism. Toronto: House of Anansi Press, 1981.

Eddins, Dwight. The Gnostic Pynchon. Bloomington; Indianapolis: Indiana University Press, 1990.

Frye, Northrop. Words With Power: Being a Second Study of 'The Bible and Literature.' Markham, Ont.: Penguin, 1990.

Harnack, Adolph. History of Dogma. Trans. Neil Buchanan. 7 vols. New York: Russell and Russell, 1958.

Mead, G.R.S. Pistis Sophia: A Gnostic Miscellany. London: John M. Watkins, 1963.

Mycak, Sonia. In Search of the Split Subject: Psychoanalysis, Phenomenology, and the novels of Margaret Atwood. Toronto: ECW Press, 1996.

Pagels, Elaine. The Origin of Satan. New York: Random House, 1995.

Stein, Murray, ed. Jung on Evil. Princeton, NJ: Princeton University Press, 1995.

York, Lorraine M., ed. Various Atwoods: Essays on the Later Poems, Short Fiction, and Novels. Concord, Ont.: House of Anansi Press, 1995. 